Discussion Paper No. 09-076

Noncognitive Skills in Economics:

Models, Measurement, and Empirical Evidence

Hendrik Thiel and Stephan L. Thomsen

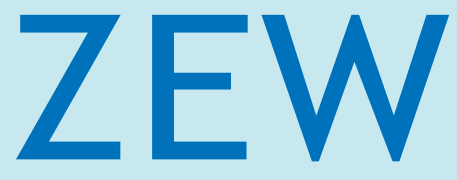

Zentrum für Europäische Wirtschaftsforschung $\mathrm{GmbH}$

Centre for European

Economic Research 
Discussion Paper No. 09-076

\section{Noncognitive Skills in Economics: \\ Models, Measurement, and Empirical Evidence}

Hendrik Thiel and Stephan L. Thomsen

Download this ZEW Discussion Paper from our ftp server:

ftp://ftp.zew.de/pub/zew-docs/dp/dp09076.pdf

Die Discussion Papers dienen einer möglichst schnellen Verbreitung von neueren Forschungsarbeiten des ZEW. Die Beiträge liegen in alleiniger Verantwortung der Autoren und stellen nicht notwendigerweise die Meinung des ZEW dar.

Discussion Papers are intended to make results of ZEW research promptly available to other economists in order to encourage discussion and suggestions for revisions. The authors are solely responsible for the contents which do not necessarily represent the opinion of the ZEW. 


\section{Non-technical Summary}

Measuring unobserved individual ability is a core challenge of the analysis of questions related to human capital development. For that purpose, concepts from psychology, predominantly measures of IQ have become established means in empirical economics. However, many issues of individual differences and their consequences still remain unexplained. Recently, the consideration of personality traits in the economic literature has started and substantially contributes to narrow the gap of explained and unexplained aspects of human capital. With regard to human capital theory, economists usually refer to noncognitive skills in this context.

The paper at hand provides an overview on the growing but influential literature in the field. The composition and impact of noncognitive skills on certain outcomes are usually less familiar to economists and, moreover, in comparison to cognition, these skills exhibit a larger scope for interventions. Therefore, the text should serve as a short introductory guide to a wide audience of readers in economics. This audience includes nonspecialist readers and experts, too. Based on the contemporary literature, central questions and findings regarding measurement, theoretical modeling, and the empirical estimates are summarized. The obtained results shed light on the relation between parental investments, skill formation in general, and later outcomes.

From this review, some features highly relevant for the development of human capital skills could be identified: Early investments are the most crucial inputs into skill formation in general and should be followed by later investments. As a consequence, early neglect usually cannot be compensated in the aftermath since returns to education diminish. Even more importantly, the impact of acquired noncognitive skills on various outcomes throughout the life course is more eminent than assumed until recently. Not only schooling and later earnings, but also important social and health-related outcomes are strongly affected. 


\section{Das Wichtigste in Kürze}

Die Erfassung der unbeobachtbaren individuellen Fähigkeiten ist die wesentliche Anforderung in der empirischen Untersuchung humankapitaltheoretisch motivierter Fragestellungen. Hierzu werden seit langem Konzepte aus der Psychologie verwendet, insbesondere zur Messung kognitiver Fähigkeiten wie z.B. dem IQ. Wesentliche Teile individueller Unterschiede bleiben bei einer solchen Approximation aber unerklärt. Der Einbezug von Persönlichkeitsmerkmalen in der jüngeren Forschung hat zu einem erheblichen Erkenntnisgewinn in der Erklärung dieser Unterschiede beigetragen. Entsprechend der Terminologie der Humankapitaltheorie ist in der ökonomischen Literatur der Begriff nicht-kognitive Fähigkeiten anstelle der Persönlichkeitsmerkmale gebräuchlich.

Der vorliegende Aufsatz gibt einen Überblick über die stark gewachsene, relevante Literatur, die sich der Untersuchung nicht-kognitiver Fähigkeiten in ökonomischen Problemzusammenhängen widmet. Der Schwerpunkt liegt dabei auf der Messung und Erfassung dieser Fähigkeiten, der theoretischen Erklärung des Entwicklungsprozesses über den Lebenszyklus und der verfügbaren empirischen Evidenz. Die Validität der jeweiligen psychometrischen Konzepte ist jedoch nicht abschließend geklärt. Die Mehrzahl der Maße ist durch Messfehler, Rückwärtskausalität oder latente Einflüsse anderer Faktoren verzerrt. Zum besseren Verständnis der Humankapitalentwicklung wird auf ein erweitertes theoretisches Modell Bezug genommen, das explizit kognitive und nicht-kognitive Fähigkeiten berücksichtigt, und die wichtigsten Erkenntnisse werden diskutiert. Aufbauend auf diesen Grundlagen wird anschließend die empirische Literatur anhand der zugrunde liegenden Forschungsfragen klassifiziert und die zentralen Resultate werden zusammengefasst.

Als zentrale Ergebnisse aus dieser Übersicht lassen sich die folgenden identifizieren: Frühkindliche Investitionen sind die entscheidenden Inputs in die Fähigkeitsentwicklung, sie sollten aber durch spätere Investitionen ergänzt werden. Wichtige Konsequenz hieraus ist, dass Vernachlässigungen in diesem Alter im Nachhinein nur schwer zu kompensieren sind, da Bildungsinvestitionen einem abnehmenden Grenzertrag unterliegen. Darüber hinaus kann die Tatsache, dass nicht-kognitive Fähigkeiten einen weitaus nachhaltigeren Einfluss auf viele Größen im Lebensverlauf haben als bislang angenommen, als fundamental und essenziell beurteilt werden. $\mathrm{Zu}$ den beeinflussten Größen zählen neben Schulabschluss und Verdienst auch soziale Ergebnisse und die Gesundheit. 


\title{
Noncognitive Skills in ECONOMics: Models, Measurement, and Empirical Evidence*
}

\author{
Hendrik Thiel ${ }^{\dagger}$ \\ University of Magdeburg \\ Stephan L. Thomsen ${ }^{\ddagger}$ \\ University of Magdeburg \& ZEW, Mannheim
}

This version: November 24, 2009

\begin{abstract}
There is an increasing economic literature considering personality. This paper provides an overview on the role of these skills regarding three main aspects of economic analysis: measurement, theoretical modeling, and empirical estimates. Based on the relevant literature from different disciplines, the common psychometric measures used to assess personality are discussed. A recently proposed theoretical framework of human capital production takes personality explicitly into account. It is reviewed to clarify the understanding of crucial features of skill development. Based on these foundations, the main results of the empirical literature regarding noncognitive skills are classified along the research questions and summarized.
\end{abstract}

Keywords: noncognitive skills, personality, human capital formation, psychometric measures

JEL Classification: I20, I28, J12, J24, J31

\footnotetext{
${ }^{*}$ We thank Katja Coneus, Friedhelm Pfeiffer and the participants of the University of Magdeburg Mentoring Seminar 2009, Potsdam, for valuable comments. Financial support from the Stifterverband für die Deutsche Wissenschaft (Claussen-Simon-Stiftung) is gratefully acknowledged. The usual disclaimer applies.

${ }^{\dagger}$ Hendrik Thiel is Research Assistant at the Chair of Labor Economics at Otto-von-Guericke-University Magdeburg. Address: PO Box 4120, D-39016 Magdeburg, e-mail: hendrik.thiel@ovgu.de, phone: +49 3916718324.

${ }^{\ddagger}$ Stephan L. Thomsen is Assistant Professor of Labor Economics at Otto-von-Guericke-University Magdeburg and Research Associate at the Centre for European Economic Research (ZEW) Mannheim.

Address: PO Box 4120, D-39016 Magdeburg, e-mail: stephan.thomsen@ovgu.de, phone: +49 391 6718431, fax: +493916711700.
} 


\section{Introduction}

The seminal theoretical models proposed by Becker (1964) and Ben-Porath (1967) provide a sensible way to analyze the relationship between individual ability, educational investment, and economic outcomes in terms of educational success or labor market productivity. However, measuring ability empirically to operationalize the theoretically derived parameters is not a straightforward task. For a long time, measures of cognitive ability, like IQ, have been used for approximation. The consideration of IQ has been (at least partly) so common due to the lack of further reliable measures. ${ }^{1}$ Nevertheless, cognitive ability provides a non-comprehensive characterization of individual's ability since personality is important, too.

In personality psychology, individual differences due to personality have been a core topic for a long period of time (see, e.g., Roberts, Kuncel, Shiner, Caspi, and Goldberg, 2007). Recently, economists have started to take these findings into account and to emphasize the crucial role of personality in explaining economic issues. The consideration of psychometric measures contributes to a better understanding of the genesis and the evolvement of productive skills in general, not only those acquired by formal education and labor market experience.

This paper provides an overview addressing the main topics of embedding personality in economics. The overview at hand differs from more detailed survey articles concentrating on particular aspects, like e.g. Cunha, Heckman, Lochner, and Masterov (2006) who provide a comprehensive discussion and formal foundation of the process of skill formation and corresponding results. ${ }^{2}$ The composition and impact of noncognitive skills on certain outcomes are usually less familiar to economists and, moreover, in comparison to cognition, these skills exhibit a larger scope for interventions. Therefore, the text should

$\overline{1}$ There are a number of studies using IQ as a measure for general ability, e.g., Hause (1972), Leibowitz (1974), Bound, Griliches, and Hall (1986), and Blackburn and Neumark (1992). See also Griliches (1977) for an early overview.

2 See also Cunha and Heckman (2007) for a theoretical formalization of the acquisition and development of cognitive and noncognitive skills before adulthood and Heckman (2007) for a consideration of health constitution in this context. The latter aspects are reviewed by Currie (2009). 
serve as a short introductory guide to a wide audience of readers in economics. This audience includes nonspecialist readers and experts, too. Based on the contemporary literature, central questions and findings regarding measurement, theoretical modeling, and the empirical estimates are summarized. The obtained results shed light on the relation between parental investments, skill formation in general, and later outcomes.

To do so, we will introduce definitions of the relevant concepts that are not used in a mutual exclusive way in the literature so far in the next section. After that, the common psychometric measures for human personality will be presented. The variety of possible approaches point to the still ongoing debate on correct measurement, and, therefore, the potential drawbacks of the different approaches will be emphasized. In addition, results from an evolving field of the literature which relate magnitudes of personality to economic preference parameters will be summarized.

In order to capture the role of noncognitive skills correctly, the interdependence of the formation process with cognitive skills has to be regarded. Hence, there are recent efforts in the literature to improve models of the formation of human capital throughout lifetime with explicit incorporation of personality traits and cognitive skills instead of general ability. In particular, the seminal model of the skill-production technology proposed by Cunha and Heckman (2007) provides crucial insights and will be briefly introduced in section three.

The theoretical model strongly builds on widespread empirical evidence from US intervention programs which aim at the improvement of educational and social circumstances for children from high-risk areas. We will summarize the main inferences of this literature under particular consideration of noncognitive skills in section four. After that, the main findings from a second set of empirical studies analyzing the influence of personality on wages and educational attainment, but also on health and social outcomes will be presented. The final section provides conclusions and briefly addresses issues not discussed. 


\section{Noncognitive Skills: Definitions and Measurement}

\subsection{Definitions}

In general, noncognitive skills constitute capabilities related to a person's personality and comprise a wide range of facets. ${ }^{3}$ Personality traits are the persisting attributes of human behavior, i.e. they are non-situational (see Allport, 1937). Prominent examples for personality traits are self-discipline, self-control, agreeableness, self-esteem, or conscientiousness. Since few issues of human behavior actually are devoid of cognition, a precise separation of the terms cognitive and noncognitive is rather notional. For instance, emotional intelligence (see Borghans, Duckworth, Heckman, and ter Weel, 2008), which describes the processing ability that designates the consequences of feelings and the resulting behavior, is a marginal case in terms of this distinction. Fortunately, the traits of interest for most topics in economics are more easily discriminable and, thus, the notations cognitive and noncognitive suffices. In psychology, however, this term is uncommon and one refers to personality traits.

Two familiar conceptions in the human capital literature are skills and abilities. The seminal work of Becker (1964) claims a binary stratification in which abilities are innate and genetically predetermined, whereas skills are acquired over the life cycle. Within that view, skills and abilities are two competing rather than joint determinants of potential outcomes. To that effect, Becker (1964) figures out that acquired skills possess higher explanatory power for future earnings than innate abilities do.

The contrary view is advocated in the classical signaling literature (see, e.g., Spence, 1973) which essentially discards the concept of lifelong learning and treats educational attainment as a signal for inherited abilities. Contrary to these extreme views, the more recent human capital literature emphasizes that innate abilities provide the initial input in the process of human capital formation (see Ben-Porath, 1967; Becker and Tomes, 1986; Aiyagari, Greenwood, and Seshadri, 2002). As we will show in section three, the

$3 \quad$ For example, Allport and Odbert (1936) obtained about 18,000 attributes describing individual differences in the English language. 
model on human capital formation proposed by Cunha and Heckman (2007) permits to use both terms interchangeably henceforth.

\subsection{Measurement}

In order to yield appropriate measures for personality traits economists utilize knowledge and measures from personality psychology. There are long-lasting discussions concerning appropriate measures for the variety of traits and the resulting personality models in psychology; respective overviews are provided, e.g., by Roberts, Harms, Smith, Wood, and Webb (2006) or Borghans, Duckworth, Heckman, and ter Weel (2008).

One distinction refers to how the personality measures are surveyed. Self-reported measures are convincing due to their simple implementation but implicitly assume that personality is consciously assessable, which does not generally hold. For instance, infants and children are not capable of doing so. On the other hand, there are certain traits hardly assessable by observational ratings of persons from the social environment. Ratings provided by experts are more reliable in those cases, but rather infeasible outside of clinical assessments. As the potential distortions subsequently discussed will show, the additional effort entailed by expert ratings may be worthwhile.

The second discussion is on how comprehensively a measure should project the human personality. Besides various scales for the magnitude of distinct traits, there is a large number of taxonomies mapping human personality as a whole. These models are denoted personality inventories.

As the subsequent discussion will show, it is not possible to generally define which kind of measure is the most sophisticated one. The adequacy or appropriateness of the single measures depends on a number of factors like the specifics of the respondents and the circumstances of the assessment, and on dimension and ensuing effort of the assessment.

Personality Inventories. Most taxonomies mapping human personality presume a hierarchical structure. According to Cattell (1971), a comparable setup applies to general 
IQ, which includes fluid intelligence, that is, the ability to solve novel problems, and crystallized intelligence, comprising knowledge and developed skills.

In case of personality the level of abstraction is lower. Despite early efforts by Webb (1915) to identify a general magnitude for personality, later models usually assume at least three major factors. Table 1 provides an overview on the commonly used concepts in the literature.

< Include Table 1 about here >

A widely accepted taxonomy is the so-called Big Five Model (see Goldberg, 1971). Since the personality structure is assumed to be hierarchical, each factor of is further divided into more specific sub-factors or facets. However, the five factor pattern is not without controversy as indicated by the alternative concepts included in Table 1. Some authors suggest a lower number of factors, whereas others proclaim a higher number. Eysenck (1991), for example, provides a model with just three factors; Digman (1997) curtails the Big Five distinction to only two higher-order factors. ${ }^{4}$ In contrast to that, Hough (1992) proposes a more stratified version of the Big Five taxonomy, the so-called Big Nine. This variety of alternative concepts to characterize personality traits points to the still ongoing debate about classification and affiliation of personality facets.

Nevertheless, a common property of the different taxonomies is that motivation or related factors are not explicitly considered (see Borghans, Duckworth, Heckman, and ter Weel, 2008). Common interpretations of motivation separate it from personality traits and manifest it as an additional determinant of human behavior, since motivation may differ from the more invariant personality in terms of persistence and interference (see Roberts, Harms, Smith, Wood, and Webb, 2006, for discussion on this view). A very influential work linking individual factors and environmental stimuli in terms of motivation is the so-called theory of reciprocal determinism by Bandura (1986). This theory comprises

$4 \quad$ The factors are not presented in Table 1 since they are simply denoted metatraits without further specification. 
the concept of self-efficacy. Furthermore, measurability of motivation by self-reports is sometimes called into question (see McClelland, Koestner, and Weinberger, 1989). We omit further treatment of the motivation concept for the sake of brevity.

Since personality inventories usually build on factor analytical methods, virtually all the aforementioned concepts lack a theoretical foundation of the relationship with the outcomes under study. As a consequence, otherwise influential predictors of certain outcomes may be less important within a particular inventory. The inventories are often only valid within the specific construct. Only in a few cases neurological support for the constructs is already available (see, e.g., Canli, 2006, pertaining to the Big Five).

Personality Scales. By contrast, measures chosen with respect to certain outcomes provide criterion-related validity. Using lower-order factors often entails a gain in explanatory power, but many of these specific scales are affected by conceptual overlaps (see, e.g., Judge, Erez, Bono, and Thorensen, 2002). Prominent examples for such traits in the context of educational outcomes are self-control (see Wolfe and Johnson, 1995) and the related self-discipline (see Duckworth and Seligman, 2005).

A common example for a measure of self-control is the Brief Self-Control Scale (Tangney, Baumeister, and Boone, 2004). It includes 13 items which sum up to an index increasing with self-control. The Internal-External Locus of Control by Rotter (1966) is often perceived as a related measure, though it merely assesses an individual's attitude on how self-directed (internal) or how coincidental attainments in her or his life are. The original Locus of Control (Rotter, 1966) comprises 60 items and is scored in the internal direction, that is, the higher the score the more internal is the individual. Usually, longitudinal datasets apply abbreviated versions comprising only 23 or 10 items. A similar scale for Locus of Control is the Internal Control Index (Duttweiler, 1984), a 28-item scale that likewise scores in the internal direction.

Self-esteem provides a further important determinant of educational and labor market outcomes (see, e.g., Heckman, Stixrud, and Urzua, 2006). It is often quantified by the 
Rosenberg Self-Esteem Scale (Rosenberg, 1965), a 10-item scale also increasing with respect to the extent of self-esteem.

Further Measures. When a respondent is too young for self-reporting, generally observational reports by parents or teachers are used instead. A prominent teacher rating scale including 26 statements is the Rutter Child Scale B (Rutter, 1967). Another measure is the Self-Control Rating Scale (Kendall and Wilcox, 1979), a 33-item scale indicating the ability of inhibiting impulsiveness. Analogous rating approaches are the Bristol Social Adjustment Guide (BSAG) and the Behavioral Problem Index (BPI, Peterson and Zill, 1986) which likewise include explicit statements on children's behavior. A related concept to behavioral measures - at least in early childhood - is temperament, which rather refers to behavioral tendencies than pure behavioral acts. An influential and often adopted model has been suggested by Thomas, Chess, and Birch (1968) which stratifies temperament in nine categories each grouped into three types of intensity. There are further established displays of temperament, e.g., Buss and Plomin (1975) and Rothbart $(1981)^{5}$, but also more contemporary literature is still involved in this topic (see, e.g., Rothbart and Bates, 2006). The previously mentioned personality measures primarily originate from personality psychology, whereas temperamental measures are mainly studied by developmental psychologists. Meanwhile, some interrelation has been established between both concepts. For instance, Caspi (2000) reveals links between the extent of temperamental facets at age 3 and personality at adulthood. Temperament at infancy and early childhood designates later personality but is descending in affecting behavior as the individual matures. According to Thomas and Chess (1977) purely temperamental expressions at later age are only likely in case of being faced with a new environmental setting. Unfortunately, the inferences from studies linking temperament and personality are far from being conclusive (see Rothbart, Ahadi, and Adams, 2000; Shiner and Caspi, 2003; Caspi, Roberts, and Shiner, 2005, for a review of the literature). A recently proposed alternative to measure personality traits is the Day Reconstruction

$5 \quad$ See Goldsmith et al. (1987) for an overview on these temperamental measures. 
Method (DRM, see Kahneman, Krueger, Schkade, Schwarz, and Stone, 2004). The DRM asks respondents to partition the previous day to form a time diary and to sample the respective experiences. The revealed behaviorial patterns could then be used to conclude about certain personality traits. For instance, Krueger and Schkade (2008) apply the method to obtain a measure of respondent's gregariousness. The origin (and to date more frequent application) of DRM is the research of well-being (see Kahneman and Krueger, 2006, for an overview).

Measurement Error and Validity. In personality psychology, there is a persistent controversy whether self-reported information or observable data are more reliable to measure individual personality. Roberts, Harms, Smith, Wood, and Webb (2006) review a number of studies in which the usefulness of both rating types has been tested across a variety of domains. They conclude that the answer to this question depends on the characteristic of interest. To mention only two examples: For traits related to typical social settings, like meeting a stranger or having a discussion, observer ratings tend to predict behavior better than self-reports since the potential for disorder in self-perception is high. For instance, what the narrator of a joke believes to be funny is not perceived by others in the same manner. Vice versa, self-reported personality ratings are more strongly related to assessments of emotional issues driven by interior processes and less shared with others. An illustrative example for this is a person annoyed by depressions who would usually try to conceal his or her problems from others.

Moreover, the potential for faking, i.e. understating and overstating the true situation, is higher for measures of personality than in case of standardized tests for noncognitive skills, like the IQ-test. If the test is administered for making a hiring decision, such a behavior may be conscious. Conversely, the same behavior may be subconsciously induced when the assessment is anonymous. In either case other personality traits or cognitive capabilities presumably influence the respondent's behavior. Borghans, Meijers, and ter Weel (2008) reveal an interrelation between personality and incentive responsiveness. Morgeson et al. (2007), providing a more detailed discussion on this 
issue, suggest that correcting for intentional faking does not improve the validity of measures. Nonetheless, other distorting forces accompanying the influences of latently operating traits, like rewards and context variables, should be considered. For instance, fulfilling a certain social role at the time the assessment takes place could be regarded as a context variable (see Wood, 2007). ${ }^{6}$ In order to maintain external validity and comparability it is therefore appropriate to standardize the variables to adjust away potential effects of incentives and other environmental factors. Otherwise the scope for potential biases is large.

Personality and Economic Preference Parameters. It is clearly intuitive to assume a relationship between the expressions of cognitive and noncognitive skills and the magnitudes of economic preference parameters. For instance, the patience of an individual may affect her or his time preference and, hence, the intertemporal utility function relative to others. Most traditional human capital frameworks rely on exogenous market interest rates or at least on not further specified personal discount rates as a basis for agent's optimization. As Borghans, Duckworth, Heckman, and ter Weel (2008) summarize, from an economic point of view it is meaningful to relate personality concepts to common parameters like time-, risk-, and leisure-preferences, but also to the more recently studied concepts of altruism and reciprocity (see, e.g., Fehr and Schmidt, 2006, for an overview on these other-regarding preferences). Unfortunately, the prevailing evidence on interrelations between skills and economic preference parameters is still vague and little sustainable.

Borghans, Meijers, and ter Weel (2008) examine potential links between noncognitive traits and responsiveness for incentives in answering cognitive tests. The responsiveness is captured by common economic preference parameters. In addition to conventional selfreported personality questionnaires the respondents have to answer questions in which they are asked to assess the trade-off between current and future rewards, certain and

$\overline{6} \quad$ As section 4 will briefly address, permanently fulfilling certain social roles does not solely affect measures of personality, but induces changes of specific personality traits as well. 
risky rewards, and money and leisure. Most correlations between personality traits and economic parameters are significant, but modestly only. For instance, the authors find a negative correlation between the Internal Locus of Control and the personal discountrate of -0.1178 ( $p=0.0000)$ and similarly a correlation between emotional stability and risk-preference of $-0.1177(p=0.0000)$ that are both intuitively plausible. Obviously, correlational analysis does not imply a causal relationship per se and spurious relationships are not regarded. Borghans, Meijers, and ter Weel (2008) therefore emphasize the need for further research to amend these still preliminary insights.

Dohmen, Falk, Huffman, and Sunde (2008) use data from the German Socioeconomic Panel (SOEP) to reveal possible relationships between Big Five personality traits, measures of reciprocity, and trust. All Big Five factors exert significant positive influence on positive reciprocity, especially conscientiousness and agreeableness. Moreover, neuroticism promotes trust and negative reciprocity. In addition, see Borghans, Duckworth, Heckman, and ter Weel (2008) for a summary of the sparse literature examining altruism or preferences for leisure and their relation to personality concepts. As the discussion below will address, these preliminary results are likely to be subject to substantial biases due to measurement error and misspecification.

Furthermore, analyses of that type are difficult to validate since cognition or at least interactions with cognition are omitted. According to Dohmen, Falk, Huffman, and Sunde (2007) lower cognitive abilities are associated with higher risk-aversion and impatience, that is, higher discount rates. This is in line with the meta-analysis of Shamosh and Gray (2008) who likewise reveal a moderately inverted relationship between cognitive abilities and discount rates. Scholastic aptitude is positively correlated with patience and negatively correlated with risk-aversion (see Benjamin, Brown, and Shapiro, 2006). Generally, questionnaire assessments of preference parameters are likely to suffer from a number of potential problems. The observed preferences are either simply stated, i.e., on hypothetical items, or if revealed, only within a non-market setting. Yet, it is ambiguous whether preferences for artificial and real market settings are identical (see 
Kirby, 1997; Madden, Begotka, Raiff, and Kastern, 2003, for two opposing views). If an experimental assessment embodies real rewards, choosing the respective payoffs binds the participant to maintain his choice. In a real life setting, however, the individual also has to withstand other opportunities permanently, and there may be a higher degree of uncertainty for future payoffs. It could prove difficult to partial out time preference from risk-aversion (see Borghans, Duckworth, Heckman, and ter Weel, 2008, and the related literature they refer to for further details). Moreover, measures of time preference may be subject to framing effects. Non-linearities with respect to the payoffs are also likely and limit the external validity of experimental findings.

\section{Economic Modeling}

In the following we will present an intuitive outline of Cunha-Heckman's technology of skill formation. Introducing the crucial features of the technology is useful, since it allows a formal reading of the formation process of both cognitive and noncognitive skills and, therefore, simplifies its comprehension. The model was initially presented in Cunha, Heckman, Lochner, and Masterov (2006) and builds on the literature on childhood and adolescence interventions reviewed there. Two further variations are provided in Cunha and Heckman (2007) and Heckman (2007). Basically, it explicitly regards cognitive and noncognitive skills in a flexible way to model changes in these factors over time in response to investments. This joint contemplation is essential since there is an interaction in the development of both.

The process of skill development is formalized by means of a production technology. This approach traces back to the seminal work of Ben-Porath (1967). However, since the aim of the Ben-Porath model is to formalize the human capital investment profile over the life cycle, the optimal strategy crucially depends on opportunity costs, i.e., forgone earnings. Although it may be a reasonable assumption for adulthood, this calculus has clear limitations in explaining human capital development in a setting in which parents decide on investing in their children. 
Cunha and Heckman (2007) and Heckman (2007) focus on human capital acquisition throughout childhood and adolescence. They allow for diversity of investments, skills, and abilities, as well as the possibility of different production technologies at different stages. The general technology is specified as follows

$$
\theta_{t+1}=f_{t}\left(\theta_{t}, I_{t}\right), t \in\{1, \ldots, T\},
$$

where $T$ is the end of childhood, $I_{t}$ is the vector of current period's investments, and $\theta_{t+1}$ and $\theta_{t}$ are the stocks of skills in the respective periods. This setup involves two important features: self-productivity and dynamic complementarity. Self-productivity postulates that skills acquired at one stage enhance the formation of skills at later stages. Dynamic complementarity considers the issue that a higher level of skills at an earlier stage enhances the productivity of investments in the ensuing stages. It results from conventional complementarity between $I_{t}$ and $\theta_{t}$ and the recursive fashion of the production technology. Vice versa, it also captures that early investments should be followed by later ones.

The empirical literature on skill formation suggests critical and sensitive periods in acquiring certain skills, i.e., there are types of skills which are exclusively or at least predominantly malleable in a special period (see Knudsen, 2004). The Cunha-Heckman model considers this by embedding childhood into a multistage framework. Involving $t=1$, for example, as a prenatal period permits gene expression or health at birth to be affected by parental investments. This implies that also innate abilities are susceptible and subject to the multiplier effect induced by self-productivity and dynamic complementarity.

In order to distinguish the evolvement of cognitive and noncognitive skills as ingredients for later human capital, the technology has to be further specified. Cunha and Heckman choose a CES technology that allows for different elasticities of substitution between 
inputs at different stages and for different skills. This yields

$$
\theta_{t+1}^{j}=\left[\gamma_{1, t}^{j}\left(I_{t}\right)^{\rho_{t}^{j}}+\gamma_{2, t}^{j}\left(\theta_{t}^{C}\right)^{\rho_{t}^{j}}+\left(1-\gamma_{1, t}^{j}-\gamma_{2, t}^{j}\right)\left(\theta_{t}^{N}\right)^{\rho_{t}^{j}}\right]^{\frac{1}{\rho_{t}^{j}}}
$$

with $j \in\{C, N\}$, denoting cognitive (C) and noncognitive (N) skills, $\rho_{t}^{j}<1$ and $t \in$ $\{1, \ldots, T\}$. The notation in eq. (2) therefore accounts for cross-productivity between cognitive and noncognitive skills. The CES specification also allows for the explicit incorporation of additional issues like parental characteristics, parental environment, or children's health capabilities (see, e.g., Coneus and Pfeiffer, 2007; Cunha and Heckman, 2009).

When adulthood is attained in period $T+1$, the disposable stock of human capital can be regarded as the outcome of the acquired cognitive and noncognitive skills developed up to $T$, potentially in a specification as in eq. (2).

The parameter values in eq. (2) have a direct impact on the optimal investment over time. In case of non-complementarity, i.e., when $\rho=1$ holds for particular periods or skills, there is no advantage of investing early compared to later. The parental investment profile fully depends on the ratio of the involved multipliers, $\gamma$, and the market interest rate for the respective time horizon. ${ }^{7}$ As $\rho$ decreases towards minus infinity the role of the multiplier shrinks. Hence, the balance between earlier and later investments becomes more important.

The framework presented so far does not take account of budget constraints usually binding investment decisions. Cunha and Heckman (2007) and Cunha, Heckman, Lochner, and Masterov (2006) derive different implications for different perfect and imperfect market settings on investment behavior. As sketched by Cunha and Heckman (2009), further extensions of the model could comprise formalizations of the investment behavior and the outcome generating process. Up to now, the underlying patterns of parental and children's preferences concerning child's outcomes and the respective investments

$7 \quad$ Taxation might be another determinant, see, e.g., Benabou (2002) and Heckman, Lochner, and Todd (2003). 
are not straightforward and therefore less explored. See Becker and Mulligan (1997), Borghans, Duckworth, Heckman, and ter Weel (2008), and Cunha and Heckman (2009) for a further discussion.

\section{Empirical Evidence}

Subsequently, we will review the available evidence that confirms the presumed features of the production technology with particular regard to noncognitive skills. As implicated by the theoretical model, cognitive and noncognitive skills jointly evolve and cross-fertilize. However, cognitive skills (in particular, the IQ) have been proven to stabilize way more early in life course. This fact turns out to be extremely useful when concluding about personality formation by using data that mainly comprise measures of cognitive abilities and scholastic achievement. Therefore, some inferences on the properties of skill formation in terms of noncognitive skills are only implicitly derived from the available data. After having pinpointed the sources of inequalities in individual skills and the potential for remediation, section 4.3 will review a number of studies analyzing consequences of these differences.

\subsection{Accumulation of Skills}

Cunha, Heckman, Lochner, and Masterov (2006) refer to a range of intervention studies, primary from the US, which capture only certain periods of childhood and adolescence. As a consequence the adopted evidence is rather implicit, particularly in case of noncognitive skills. Besides the studies available for the US, there is a growing empirical evidence for European countries. However, by now there are virtually no proper program evaluations due to the still inferior data situation (see Wössmann, 2008, for a summary of evidence). Thus, the majority of studies rely on descriptive associations without revelations of causal relationships.

Initially, two crucial features referring to the inheritability of cognitive and noncognitive 
skills should be emphasized. The multiplier effect mentioned above drives innate abilities to play a bigger role in the future if they are initially higher. Even before birth, crucial modules for future skill formation (e.g., health condition) are established by environmental influences (see Shonkoff and Phillips, 2000). Furthermore, environmental and genetic components are not additively separable. This applies not only for issues in behavioral genetics, but for gene expression in general. For instance, Fraga et al. (2005) reveal that monozygotic twins exerted to different stimuli throughout early childhood can exhibit significantly different gene expressions due to differences in DNA methylation. This is in line with Turkheimer, Haley, Waldron, D'Onofrio, and Gottesman (2003) who use data from the National Collaborative Perinatal Project (NCPP) to fit a model that associates IQ with socioeconomic status. They show that a simple additive model structure is inappropriate to capture the complexity of the IQ generating process and that there are substantial interactions of genes and environment. Personality and behavioral patterns also have a genetic and an environmental component (see Bouchard and Loehlin, 2001) and the same interaction pattern applies. For instance, Caspi, McClay, Moffitt, Mill, Martin, Craig, Taylor, and Poulton (2002) show this relationship for conduct disorder in maltreated children. A further discussion of this nature versus nurture debate including additional empirical evidence is given in Heckman (2008) and Cunha and Heckman (2009). Both, the existence of prenatal experiences as well as gene-environment interactions, underpin why innate abilities could be regarded as the initial input into the skill formation process and not as an additive component.

Subsequently, we will address some intervention studies in order to raise evidence for the crucial skill formation features, like self-productivity and dynamic complementarity. We will focus on proving these properties in terms of noncognitive skills. However, a brief contemplation of IQ in this context is indispensable. A more detailed overview is provided in Table 2, the purpose of which is to summarize the main findings of the different studies and to allow for a comparison of the results taking into account differences in the analysis' questions, the data, and the applied methods. 
< Include Table 2 about here >

Knudsen (2004) as well as Knudsen, Heckman, Cameron, and Shonkoff (2006) attribute the existence of critical and sensitive periods to a superior susceptibility of neural circuits and brain architecture in early lifetime. This is particularly relevant for cognitive abilities in terms of IQ which become highly stable in early school age (Hopkins and Bracht, 1975). Hence, infancy is a crucial stage and early neglect can barely be remediated. This is strikingly shown by O'Connor, Rutter, Beckett, Keaveney, and Kreppner (2000) who assess cognitive abilities among a group of Romanian orphans who were adopted into UK families between 1990 and 1992 and compare them at ages four and six to adopted children from within the UK. The UK orphans were all placed into their new families before the age of six months. Their findings suggest that early deprived children never catch up. Another familiar example for a sensitive period is the increasing effort associated with second language acquisition as people get older (see Johnson and Newport, 1989; Newport, 1990; Knudsen, Heckman, Cameron, and Shonkoff, 2006, and the further literature noted there). ${ }^{8}$

Personality, however, is malleable up to a higher age. Intervention studies conducted at adolescence usually report gains in behavioral measures. As Table 2 illustrates, even interventions at primary school age boost scholastic performance in a lasting manner without permanently raising IQ. These findings provide implicit evidence on the susceptibility of personality beyond early childhood since the gains in scholastic performance could not be attributed to augmented intelligence. This is in line with the view in pediatric psychiatry (see, e.g., Dahl, 2004) highlighting the role of the prefrontal cortex in governing emotion and self-regulation and its malleability up into the early twenties of life. Roberts, Walton, and Viechtbauer (2006) show increasing rank-order stability of the broad Big Five factors with increasing age. However, their stability measure not peaks until age 50, though the changes after early adulthood become increasingly modest.

$8 \quad$ However, the evidence on critical periods in second language learning is not without controversy. Bialystok and Hakuta (1999) identify a number of additional driving forces, like different linguistic specifics, that may lead to an overestimation of the age effect in second language acquisition. 
They also establish that substantial mean-level changes take place beyond adolescence, that is, personality is not rigid as adulthood is reached. These changes are presumed to be normative, that is, common to all individuals. They suggest that these changes are induced by enduring shifts in social roles and role expectations.

Though neither this nor any similar type of longitudinal assessment is capable of providing detailed information on individual differences in personality changes over life course, they confirm a certain predetermination of the order within the population distribution of personality due to prior life experience. This implies that the initial environmental influence in infancy and early childhood is crucial for the development of personality. As a result of the multiplier, intervention programs tend to be more effective if provided early in life (see also Blau and Currie, 2006, for a comprehensive discussion on early childhood interventions).

A common finding of the studies summarized in Table 2 is that early interventions which involve a long-term follow-up are most successful. However, most of the gains fade out if no further efforts are made. Vice versa, sole remediation attempts in adolescence exhibit only weak effects. Studies evaluating adolescent mentoring programs, like the Big Brothers/Big Sisters (BB/BS) and the Philadelphia. The BB/BS assigns educated volunteers to youths from single parent households for the purpose of providing surrogate parenthood or at least an adult friend. Grossman and Tierney (1998) stress that meeting with mentors decreases the probability of initial drug and alcohol abuse, exertion of violence, and absence from school. Moreover, the participants had higher grade points and felt more competent in their school activities. SAS targets at public high school students and supports them in making it to college by academic and financial support. Johnson (1996) reveals a significant increase in grade point average and college attendance. However, though available cost-benefit analyses yield positive social net returns, the efficiency of interventions in adolescence is definitely lower compared to early intervention programs. These results jointly manifest the feature of dynamic complementarity.

Self-productivity, however, can be empirically assessed more directly. Coneus and Pfeiffer 
(2007) estimated the effects of the stock of skills from the prior stage on the skill level at the current period conditional on a number of different proxies for parental investments. They use data from the German Socioeconomic Panel Study (SOEP) in order to obtain estimates of the influence of early skill levels on the subsequent ones. The indicator variables for child's health, cognitive and noncognitive capability are reported by the mother, but differ between stages. After adjusting for maternal education, stage specific investments and environmental factors, there is still strong evidence on self-productivity at hand. These findings are bolstered by the results of Blomeyer, Coneus, Laucht, and Pfeiffer (2009) who use the Mannheim Study of Children at Risk (MARS) ${ }^{9}$ that merge survey data with clinical data. The findings reveal intense self-productivity indicators. The virtue of the MARS data is that the participants are mostly visually assessed by experts and, hence, the measures suffer less from the errors discussed in section 2 above. Cunha and Heckman (2006) present estimates of the skill parameters of the framework discussed in section 3 and directly quantify the degrees of self-productivity and complementarity. They use data for white males from the Children of the National Longitudinal Survey of Youth 1979 (CNLSY79). From 1986 onwards, the female participants of the National Longitudinal Survey of Youth 1979 (NLSY79) were assessed biennially. The survey comprises measures of cognitive ability, temperament, motor and social development, behavioral problems, and self-confidence of the children and of their home environment. ${ }^{10}$ The results yield strong indications of self-productivity within the production of the respective skill types. The cross-effects are weaker. Complementarity is evident for both, cognitive and noncognitive stocks, but somewhat higher in case of the former. The average parameter estimate is slightly below zero which indicates that

$9 \quad$ MARS is an acronym for the German expression Mannheimer Risikokinderstudie.

10 The estimation builds on the methodology suggested by Carneiro, Hansen, and Heckman (2003) who extend previous approaches of factor analytical identification of latent variables (e.g., Jöreskog and Goldberger, 1975; Heckman, 1981) to allow for discrete and continuous indicator variables and for more than one latent factor. Endogenous choice variables like schooling, which in turn depend on the latent factors, are also considered. The approach nonparametrically identifies the distributions of the latent factors and uses filtering techniques to obtain estimates for the technology parameters. It aims at circumventing potential biases when test scores are used as a proxy for latent abilities and when inputs are endogenous. An anchoring procedure is implemented since the test scores per se exhibit no natural metric. 
the production technology could be approximated well by a Cobb-Douglas function. A slightly different identification strategy yielding similar results is provided by Cunha and Heckman (2008).

\subsection{Investments in Capabilities and their Indicators}

The early intervention programs in Table 2 evaluated to be most successful are those facilitating parenting and home environment in addition to schooling. This view is in line with the relatively weak effects of school resource enhancements or the frequently claimed class-size reduction (see Card and Krueger, 1996). The properties of skill formation suggest that schooling, in particular post-primary-schooling, is only an inferior factor in fostering skill development, since the more important fundament is already placed in preschool age. As Segal (2008) points out, classroom behavior in adolescence is determined by family characteristics and by incentives, the impact of which in turn depends on personality. Family background and social environment, especially in preschool age, play the most crucial role.

Family income may provide a good proxy. In the United States and in European countries, compulsory school attendance is regulated by law and free of tuition in case of public schools. Regarding higher education Cunha, Heckman, Lochner, and Masterov (2006) show substantial differences in college attendance rates of 18 to 24 year old American males when classifying them by their parental income in the late adolescent years. A straightforward interpretation of the revealed pattern is that the budget constraints affect the resources required to finance a college education in child's adolescent years. This is the common and most obvious interpretation and at the same time the most influential one in politics. Vandenberghe (2007), who analyzes several European countries, reveals similar results for Germany and Belgium, where due to low or even no tuition fees short-term budget constraints should play a minor role. Moreover, there are small effects established from Polish data and moderate effects are found for the UK and Hungary. 
Compared to the US, tuition fees for higher education are usually lower in Europe or even comprise only administration charges (see EAEAC, 2007, for more details on tuition for higher education in Europe). Carneiro and Heckman (2002) and Carneiro and Heckman (2003) assess the issue of short-run credit constraints and point out that parental income is of minor importance only. If scholastic ability is taken into account, decomposing the gap between NLSY minority youths and whites in college attendance yields that at most eight percent of the adolescents in the assessed sample are inhibited by short-run liquidity constraints. In case of four-year college the percentage of short-term constrained adolescents approaches zero. A corresponding explanation is that family income is highly intertemporally correlated throughout the life cycle. Therefore, higher abilities in college age are mainly attributable to higher abilities in childhood and not simply to lower educational opportunities entailed by inferior financial endowment. The evidence suggests that short-run credit constraints likewise affect the choice for enrollment to higher education but that they are clearly dominated by the long-run constraints and the respective educational tracks. In less developed countries this weighting is likely to translocate in favor of short-run constraints (see Cunha and Heckman, 2009).

Hence, due to the nature of the skill formation process budget constraints appear to be influential especially in early childhood, but with sustainable consequences for the future. However, the role of family income in childhood could also be conceived to be more ambiguous since it is only a crude indicator of parenting quality. As Currie (2009) suggests, parents obtaining higher labor market returns may invest less time in children, but may also compensate this neglect by provision of substituting goods. On the other hand low-income parents may self-select into environmental settings and behavioral patterns due to adherent personality traits, like a lower resilience to adversity (see, e.g., Masten, Burt, and Coatsworth, 2006), and simply spend less time on children, though available. In the end, parental effort is the decisive driving force and most measures are only crude indicators. Rutter (2006) and Heckman (2008) summarize a bundle of studies supporting these findings. Based on NLSY79 data, Cunha and Heckman (2006) show that among all components of the Home Observation Measurement of the 
Environment - Short Form (HOME-SF) the number of books is the best indicator of parental investments, but attenuates with age.

\subsection{Outcomes and Pathways of Transmission}

We will now focus on the economic returns generated by investments in noncognitive skills. For that purpose we subsequently distinguish direct effects on wages and latent ones through other outcomes also valued in the market, primarily formal education. Table 3 arranges additional outcomes over the life course in a chronological order.

\subsubsection{Direct Impact on Wages}

Until recently, noncognitive skills have not played an important role in explaining labor market outcomes. Bowles, Gintis, and Osborne (2001) review early explanations of wage differentials due to personality and stress that it is important to distinguish different scopes of the labor market. Two illustrative examples demonstrate this: In a working environment where monitoring is difficult, behavioral traits like truth telling may be higher rewarded than in other cases. Considering a low-skill labor market docility, dependability, and persistence may be highly rewarded, whereas self-direction may generate higher earnings for someone who is a white collar worker.

It is difficult to determine if certain traits increase wages by affecting productivity or if market mechanisms additionally induce wage premiums for certain traits. On a very general level Borghans, ter Weel, and Weinberg (2008) show that supply and demand for workers more or less endowed with directness relative to caring create a wage premium for directness. Another explanation is that the society solidifies certain expectations about appropriate traits and behavior, and rewards or punishes individuals who deviate from them in either direction. This interpretation is partially supported by the results of Mueller and Plug (2006) on the gender wage gap in the US, who show that men obtain a wage penalty for Big Five agreeableness, a trait stronger associated with women. Further 
studies addressing the impact of noncognitive skills on gender and racial wage gap, and other outcomes are summarized in Tables 3 and 4 .

< Include Table 3 about here >

Irrespectively of how the traits are valued in the market, noncognitive skills explain differences in the earnings structure well. Heckman, Stixrud, and Urzua (2006) provide empirical findings on the effects of self-control and self-esteem on log hourly wages at age 30 for distinct levels of schooling attainment by using data from the NLSY79. Especially for the lower deciles of the distribution of their compound noncognitive factor a strong influence is recognized. Flossmann, Piatek, and Wichert (2007) follow the methodology of Heckman, Stixrud, and Urzua (2006) and asses the effects of measures for noncognitive skills on gross hourly wages in Germany by applying the same estimation method to data of the SOEP. The study likewise reveals that noncognitive skills play a significant role in the wage determination process.

$<$ Include Figure 1 about here >

Figure 1 compares the net effects of an increase in noncognitive abilities on log wages obtained in the two studies. Particularly for the upper and lower deciles of the distribution the marginal effect of an increase in noncognitive skills is higher. Both results provide an important point on how personality traits affect earnings.

\subsubsection{Other Pathways}

Noncognitive and cognitive abilities do not solely affect wages, but educational outcomes as well. It is likely that the major effects of abilities are mediated through the endogenous schooling choice. The approach pursued by Heckman, Stixrud, and Urzua (2006) and Flossmann, Piatek, and Wichert (2007) accounts for this issue. Besides wages in general Heckman, Stixrud, and Urzua (2006) also assess the effects of cognitive and noncognitive 
abilities on wages given certain levels of schooling and on the probability of graduating at certain levels. For instance, for males, noncognitive skills hardly affect the probability of being a high school dropout but rather promote the probabilities of being a GED ${ }^{11}$ participant, of graduating from high school, of graduating from a two year and from a four year college.

Hence, it is of particular interest to identify which traits affect educational performance and along with it the schooling choices. Duckworth and Seligman (2005) show that self-discipline even exceeds the explanatory power of IQ in predicting performance at school. ${ }^{12}$ Highly self-disciplined adolescents outperform their peers on all inquired outcomes including average grades, achievement-test scores, and school attendance.

The choice of self-discipline as the noncognitive skill of interest is related to the findings by Wolfe and Johnson (1995). They assess which measure is most eligible for predicting grade point averages (GPA) in a sample of 201 psychology students. The outstanding GPA predictors are measures displaying the level of control and items closely related, like self-discipline. Thus, besides cognitive skills, noncognitive skills play an equally important role in affecting schooling choices or years of schooling, respectively.

Since personality is malleable throughout adolescence and IQ is fairly set earlier in life, the reverse causality is valid, too, which induces the aforementioned simultaneity. Hansen, Heckman, and Mullen (2004) use NLSY79 data to determine causal effects of schooling on achievement tests. They reveal that an additional year of schooling increases the Armed Forces Qualification Test (AFQT) score by 3 to 4 points.

Noncognitive abilities can also exhibit an intense influence on social outcomes. Closely related to the previously discussed wage achievements are employment status and mean work experience which are likewise substantially affected by the personality. ${ }^{13}$ Further outcomes like the probabilities of daily smoking, of incarceration, and of drug abuse

11 GED stands for General Educational Development and is a test that certifies college eligibility of US high school graduates.

12 They define self-discipline as a hybrid of impulsiveness and self-control.

13 See also Heckman, Stixrud, and Urzua (2006) for detailed discussion and magnitudes. 
are examined and shown to be significantly determined by noncognitive skills, albeit to different extents. Such outcomes are seemingly noneconomic with regard to wages, but even these variables are likely to be latent magnitudes of influence.

\section{Concluding Remarks}

This paper has reviewed the recent influential literature that considers the role of noncognitive skills in human capital skill formation to provide an overview on this topic to a wider audience in economics. With regard to formation and stratification of skills, the role and the timing of educational and parental investments have been proven to be crucial in the empirical literature. For a better understanding of the different types of relevant skills in human capital formation, there is an interdisciplinary exchange in research between economists and personality psychologists. In terms of either cognitive and noncognitive skills empirical research in economics strongly benefits from psychometric concepts. Nevertheless, as discussed in section 2, the proposed approaches to measure those types of skills are not completely conclusive. On the one hand, overall measures tend to be too general veiling important variation, whereas, on the other hand, measures of specific traits may put the analyst to a hard choice regarding adequacy. Generally, personality measures within an econometric framework tend to suffer from measurement error, simultaneity bias, and latent influences by other factors. The relation between personality traits and economic preference parameters is, therefore, still notional patchwork and leaves many unanswered questions.

The Cunha-Heckman model of skill formation embodies a theoretically and empirically tractable framework in many respects. Parameter estimates as those presented and discussed in section 4 provide a useful tool for future program evaluation. Using the respective program data, the Cunha-Heckman model helps to make arbitrary programs more comparable referring to the impact on latent capabilities. Applying the estimates to observational data, like the CNLSY for the US or the SOEP for Germany, alleviates the identification of counterfactuals of scheduled programs not implemented yet. As 
suggested by Cunha and Heckman (2009), a further step is to extend the current framework by appropriately modeling parents' investment behavior or frameworks for market returns to skills. But as summarized in section 4.2 the insights on parental investments are far from being definite. Attributing parental traits to interpersonal preferences like altruism and embedding these relations into economic models that are able to map the parental investment process or the generation of economic outcomes is a complicated but desirable aim.

The majority of the empirical evidence so far refers to the US; mainly due to a lack of comparable early intervention programs and assessments in other industrialized countries. However, there exists some evidence for the relative inefficiency of European programs directed towards disadvantaged adolescents or adults. At least, the qualitative inferences derived for the US, should be applicable to European countries as well. The quantitative effects revealed for US programs, on the other hand, may not be suitable for European countries in any case, since the living environment of socially deprived persons is on average less adverse. Here, further research is needed to complete the empirical picture.

Regardless of the particular effects, virtually all empirical studies suggest a joint conclusion: Early investments are the most crucial ones and should be followed by later investments. But more importantly, early neglect usually cannot be compensated in the aftermath since returns to education diminish. Hence, when supporting low-skilled individuals, there is a certain threshold in age from where subsidies are more efficient than program participation. Referring to parental investments these findings shrink the relevance of schooling environment, since the major contribution to the skill formation process has to be made in preschool age already. Moreover, the acquired stock of cognitive and noncognitive skills determines various outcomes in adulthood in equal shares.

An issue not addressed so far is whether causal inferences on the micro level may be confounded by externalities. Especially for later investments in post-primary education the revealed equity-efficiency tradeoff may be attenuated. Recent work by Moretti 
(2004) points out significant city-specific externalities of college education on wages of low-skilled workers. However, this approach does not account for long-term wage convergence due to mobility (see Heckman, 2000b). Moreover, since the spillover is induced by college graduation rate which is unlikely to be raised by investments into low-skilled population groups, the results do not necessarily contradict the equity-efficiency argument. Compared to the individual rates of return to education, unexploited externalities become minor as a certain nationwide educational standard is exceeded (see Heckman, 2000a). This is in line with the estimates provided by Acemoglu and Angrist (1999), who use US census data to exploit the exogenous variation in average schooling induced by changes in compulsory schooling law. The estimated externalities are insignificant except for the 1990 wave, where the rate of social return approaches $4 \%$.

The summarized findings of this very recent literature enrich the traditional view on human capital in economics by considering noncognitive skills as an additional determinant of lifetime labor market and social outcomes. Moreover, the essential role of infancy and early childhood in producing these outcomes is accentuated. This provides new policy implications. First, good parenting is (and will remain) the major source of educational success; this is only indirectly driven by family income. Therefore, intervention policies should be adopted already at preschool age and should primarily focus on home environment. Second, the time interval for sufficient governmental influence is more limited in case of cognitive skills than for noncognitive skills. The malleability of personality throughout adolescence and beyond provides a powerful and instantaneous policy tool. Nonetheless, this is just a crude guidance stemming from an evolving literature. Both, the optimal timing and intensity for reducing upcoming and existent inequalities remain still to be determined.

\section{References}

Acemoglu, D., and J. Angrist (1999): "How Large Are Human-Capital Externalities? Evidence from Compulsory Schooling Laws," NBER Working Papers 7444, 
National Bureau of Economic Research (NBER), Cambridge, MA.

Aiyagari, R., J. Greenwood, and A. Seshadri (2002): "Efficient Investment in Children," Journal of Economic Theory, 102(2), 290-321.

Allport, G. W. (1937): Personality: A Psychogical Interpretation. Holt, Rhinehart and Winston, New York.

Allport, G. W., and H. Odbert (1936): "Trait-Names, a Psycholexical Study," Psychological Monographs, 47(211).

Andrews, S. R., J. B. Blumenthal, D. L. Johnson, C. J. Ferguson, T. M. Lasater, P. E. Malone, and D. B. Wallace (1982): "The Skills of Mothering: A Study of Parent Child Development Centers," Monographs of the Society for Research in Child Development, 47(6), 1-83.

BandurA, A. (1986): Social Foundations of Thought and Action: A Social Cognitive Theory. Prentice Hall, New Jersey.

Becker, G., and C. Mulligan (1997): "The Endogenous Determination of Time Preference," Quarterly Journal of Economics, 112(3), 729-758.

Becker, G., And N. Tomes (1986): "Human Capital and the Rise and Fall of Families," Journal of Labor Economics, 75(4), 1-39.

Becker, G. S. (1964): Human Capital: A Theoretical and Empirical Analysis, with Special Reference to Education, The University of Chicago Press. National Bureau of Economic Research, New York, Third Edition from 1993.

Ben-Porath, Y. (1967): "The Production of Human Capital and the Life Cycle of Earnings," The Journal of Political Economy, 75(4), 352-365.

Benabou, R. (2002): "Tax and Education Policy in a Heterogeneous-Agent Economy: What Levels of Redistribution Maximize Growth and Efficiency?," Econometrica, $70(2), 481-517$. 
Benjamin, D. J., S. A. Brown, and J. M. Shapiro (2006): "Who is "Behavioral"? Cognitive Ability and Anomalous Preferences," unpublished, available at http:// papers.ssrn.com/sol3/papers.cfm?abstract_id=675264.

Bialystok, E., and K. Hakuta (1999): "Confounded Age: Linguistic and Cognitive Factors in Age Differences for Second Language Acquisition," in Second Language Acquisition and the Critical Period Hypothesis, ed. by D. Birdsong, pp. 161-181. Lawrence Erlbaum Associates.

Blackburn, M., and D. Neumark (1992): "Unobserved Ability, Efficiency Wages, and Interindustry Wage Differentials," Quarterly Journal of Economics, 107(4), 14211436.

Blau, D., And J. Currie (2006): "Preschool, Day Care, and Afterschool Care: Who's Minding the Kids?," in Handbook of the Economics of Education, ed. by E. A. Hanushek, and F. Welch, vol. 2, chap. 20, pp. 1163-1278. Elsevier B.V., Amsterdam: North-Holland.

Blomeyer, D., K. Coneus, M. Laucht, and F. Pfeiffer (2009): "Initial risk matrix, home resources, ability development and children's achievement," Journal of the European Economic Association, 7(2-3), 638-648.

Borghans, L., A. L. Duckworth, J. Heckman, and B. ter Weel (2008): "The Economics and Psychology of Personality Traits," Journal of Human Resources, 43(4), $972-1059$.

Borghans, L., H. Meijers, and B. ter Weel (2008): "The Role of Noncognitive Skills in Explaining Cognitive Test Scores," Economic Inquiry, 46(1), 2-12.

Borghans, L., B. ter Weel, and B. A. Weinberg (2008): "Interpersonal Styles and Labor Market Outcomes," Journal of Human Resources, 43(4), 815-858.

Bouchard, T. J., and J. C. Loehlin (2001): "Genes, Evolution, and Personality," Behavior Genetics, 31(3), 243-273. 
Bound, J., Z. Griliches, and B. H. Hall (1986): "Wages, Schooling and IQ of Brothers and Sisters: Do the Family Factors Differ?," International Economic Review, $27(1), 77-105$.

Bowles, S., H. Gintis, And M. Osborne (2001): "The Determinants of Earnings: A Behavioral Approach," Journal of Economic Literature, 38(4), 1137-1176.

BraAkmann, N. (2009): "The role of psychological traits for the gender gap in fulltime employment and wages: Evidence from Germany,” DIW Discussion Papers 162, German Institute for Economic Research (DIW), Berlin.

Buss, A. H., And R. Plomin (1975): A Temperament Theory of Personality Development. Wiley-Interscience, New York.

Campbell, F. A., and C. T. Ramey (1994): "Effects of Early Intervention on Intellectual and Academic Achievement: A Follow-Up Study of Children from Low-Income Families," Child Development, 65, 684-698.

Canli, T. (2006): Biology of Personality and Individual Differences. Guilford Press, New York.

Card, D., and A. Krueger (1996): "School Resources and Student Outcomes: An Overview of the Literature and New Evidence from North and South Carolina," Journal of Economic Perspectives, 10(4), 31-50.

Carneiro, P., C. Crawford, and A. Goodman (2007): "The Impact of Early Cognitive and Non-Cognitive Skills on Later Outcomes," CEE Discussion Papers 0092, Centre for the Economics of Education at the London School of Economics (CEE), London.

Carneiro, P., K. Hansen, and J. Heckman (2003): "Estimating Distributions of the Treatment Effects with an Application to the Returns to Schooling and Measurement of the Effects of Uncertainty on College Choice," International Economic Review, $44(2), 361-421$. 
Carneiro, P., and J. Heckman (2002): "The Evidence on Credit Constraints in Post-Secondary Schooling," The Economic Journal, 112(482), 705-734.

_ (2003): "Human Capital Policy," IZA Discussion Papers 821, Institute for the Study of Labor (IZA), Bonn.

Caspi, A. (2000): "The Child Is Father of the Man: Personality Continuities From Childhood to Adulthood," Journal of Child Psychology and Psychiatry, 78(1), 158172.

Caspi, A., J. McClay, T. E. Moffitt, J. Mill, J. Martin, I. W. Craig, A. TayLOR, And R. Poulton (2002): "Role of Genotype in Cycle of Violence Maltreated Children," Science, 297, 851-853.

Caspi, A., B. W. Roberts, and R. L. Shiner (2005): "Personality Development Stability and Change," Annual Review of Psychology, 56(1), 453-484.

Cattell, R. (1971): Abilities: Their Structure, Growth and Action. Houghton Mifflin, Boston.

Coneus, K., J. Gernandt, and M. SaAm (2009): "Noncognitive Skills, School Achievments and Educational Dropout," ZEW Discussion Paper 19, Centre for European Economic Research (ZEW), Mannheim.

Coneus, K., and M. Laucht (2008): "The Effect of Early Noncognitive Skills on Social Outcomes in Adolescence," ZEW Discussion Paper 115, Centre for European Economic Research (ZEW), Mannheim.

Coneus, K., And F. Pfeiffer (2007): "Self-Productivity in Early Childhood," ZEW Discussion Paper 053, Centre for European Economic Research (ZEW), Mannheim.

Costa, P. T., and R. R. McCrae (2008): "Revised NEO Personality Inventory (NEO PI-R) and NEO Five-Factor Inventory (NEO-FFI)," in The SAGE Handbook of Personality Theory and Assessment: Personality Measurement and Testing, ed. by 
G. J. Boyle, G. Matthews, and D. H. Saklofske, vol. 2, pp. 179-196. SAGE Publications Ltd., Thousand Oaks, California.

Cunha, F., And J. Heckman (2006): "Investing in our Young People," unpublished, available at http://www-news.uchicago.edu/releases/06/061115. education.pdf.

(2007): "The Technology of Skill Formation," American Economic Review, $97(2), 31-47$.

- (2008): "Formulating, Identifying and Estimating the Technology of Cognitive and Noncognitive Skill Formation," Journal of Human Resources, 43(4), 738-782.

- (2009): "The Economics and Psychology of Inequality and Human Development," Journal of the European Economic Association, 7(2/3), 320-364.

Cunha, F., J. Heckman, L. Lochner, and D. Masterov (2006): "Interpreting the Evidence on Life Cycle Skill Formation," in Handbook of the Economics of Education, ed. by E. A. Hanushek, and F. Welch, vol. 1, chap. 12, pp. 697-812. Elsevier B.V., Amsterdam: North-Holland.

Currie, J. (2009): "Healthy, Wealthy, and Wise: Socioeconomic Status, Poor Health in Childhood, and Human Capital Development," Journal of Economic Literature, $47(1), 87-122$.

Currie, J., And D. Thomas (1995): "Does Head Start Make a Difference?," American Economic Review, 85(3), 341-364.

DAhL, R. E. (2004): "Adolescent Brain Development: A Period of Vulnerabilities and Opportunities," in Annals of the New York Academy of Sciences 1021, pp. 1-22. New York Academy of Sciences.

Digman, J. M. (1997): "Higher-Order Factors of the Big Five," Journal of Personality and Social Psychology, 73(6), 1246-1256. 
Dohmen, T., A. Falk, D. Huffman, and U. Sunde (2007): "Are Risk-Aversion and Impatience Related to Cognitive Ability?," IZA Discussion Papers 2735, Institute for the Study of Labor (IZA), Bonn.

(2008): "Representative Trust and Reciprocity: Prevalence and Determinants," Economic Inquiry, 46(1), 84-90.

Duckworth, A. L., and M. Seligman (2005): "Self-Discipline Outdoes IQ in Predicting Academic Performance of Adoloscents," American Psychological Society, 16(12), 939-944.

Duttweiler, P. (1984): "The Internal Control Index: A Newly Developed Measure of Locus of Control," Educational and Psychological Measurement, 44(2), 209-221.

Education, Audiovisual and Culture Executive Agency (EACEA) (2007): "Key Data on Higher Education in Europe," European Commision.

Eysenck, H. J. (1991): "Dimensions of Personality: Sixteen, Five or Three? Criteria for a Taxonomic Paradigm," Personality and Individual Differences, 8(12), 773-790.

Fehr, E., And K. M. Schmidt (2006): "The Economics of Fairness, Reciprocity and Altruism - Experimental Evidence and New Theories," in Handbook of the Economics of Giving, Altruism and Reciprocity, ed. by S.-C. Kolm, and J. M. Ythier, vol. 1, pp. 615-699. Elsevier B.V., Amsterdam: North-Holland.

Flossmann, A., R. Piatek, and L. Wichert (2007): "Going Beyond Returns to Education: The Role of Noncognitive Skills on Wages in Germany," unpublished, available at http://www. afse.fr/docs/congres2007/docs/619716flopiwi.pdf.

Fortin, N. M. (2008): "The Gender Wage Gap among Young Adults in the United States-The Importance of Money versus People," Journal of Human Resources, 43(4), $884-918$.

Fraga, M., E. Ballestar, M. Paz, S. Ropero, F. Setien, M. Ballestar, D. Heine-Suner, J. Cigudosa, M. Urioste, J. Benitez, M. Boix-Chornet, 
A. Sanchez-Aguilera, C. Ling, E. Carlsson, P. Poulsen, A. Vaag, Z. Stephan, T. Spector, Y.-Z. Wu, C. Plass, and M. Esteller (2005): "Epigenetic Differences Arise during the Lifetime of Monozygotic Twins," Proceedings of the National Academy of Sciences of the United States of America, 102(30), 10604-10609.

Fuerst, J. S., And D. Fuerst (1993): "Chicago Experience with an Early Childhood Programme: The Special Case of the Child Parent Center Program," Educational Research, 35(3), 237-253.

GoldberG, L. (1971): “A Historical Survey of Personality Scales and Inventories," in Advances in Psychological Assessment, ed. by P. McReynolds, pp. 293-336. Science and Behavior Books, Palo Alto, California.

Goldsmith, H. H., A. H. Buss, R. Plomin, M. K. Rothbart, A. Thomas, S. Chess, R. A. Hinde, and R. B. McCall (1987): "Rounddtable: What is temperament? Four approaches," Child Development, 58, 505-529.

Griliches, Z. (1977): "Estimating the Returns to Schooling: Some Econometric Problems," Econometrica, 45(1), 1-22.

Grossman, J., And J. Tierney (1998): "Does Mentoring Work? An Impact Study of the Big Brothers Big Sisters Program," Evaluation Review, 22(3), 403-426.

Hansen, K., J. Heckman, and K. Mullen (2004): "The Effect of Schooling and Ability on Achievement Test Scores," Journal of Econometrics, 121(1/2), 39-98.

Hause, J. C. (1972): "Earnings Profile: Ability and Schooling," Journal of Political Economy, 80(3, Part 2), 108-138.

Heckman, J. (1981): "Statistical Models for Discrete Panel Data," in Structural Analysis of Discrete Data with Econometric Applications, ed. by C. Manski, and D. McFadden. The M.I.T. Press. 
(2007): "The Economics, Technology and Neuroscience of Human Capability Formation ," IZA Discussion Papers 2875, Institute for the Study of Labor (IZA), Bonn.

(2008): "Schools, Skills, and Synapses," Economic Inquiry, 46(3), 289-324.

Heckman, J., L. Lochner, And P. Todd (2003): "Fifty Years of Mincer Earinings Regression," NBER Working Papers 9732, National Bureau of Economic Research (NBER), Cambridge, MA.

Heckman, J., J. Stixrud, and S. Urzua (2006): "The Effects of Cognitive and Noncognitive Abilities on Labor Market Outcomes and Social Behavior," Journal of Labor Economics, 24(3), 411-482.

Heckman, J. J. (2000a): "Policies to Foster Human Capital," Research in Economics, $54(1), 3-56$.

(2000b): "Response to Eissa," Research in Economics, 54(1), 81-82.

Heineck, G., And S. Anger (2008): "The Returns to Cognitive Abilities and Personality Traits in Germany," DIW Discussion Papers 836, German Institute for Economic Research (DIW), Berlin.

Hill, J. L., J. Brooks-Gunn, And J. Waldfogel (2002): "Sustained Effects of High Participation in Early Intervention for Low-Birth-Weight Premature Infants," Developmental Psychology, 39(4), 730-744.

Hopkins, K., and G. Bracht (1975): "Ten-Year Stability of Verbal and Nonverbal IQ Scores," American Educational Research Journal, 12(4), 469-477.

Hough, L. M. (1992): "The "Big Five" Personality Variables - Construct Confusion: Description versus Prediction," Human Performance, 5(1), 139-155.

JACKson, D. (1976): Jackson Personality Inventory Test Manual. Research Psychologists Press, Goshen, New York. 
Johnson, A. (1996): "An Evaluation of Long-Term Impacts of the Sponsor-a-Scholar Program on Student Performance," Mathematica Policy Research Inc.

Johnson, D. L., And T. Walker (1991): “A Follow-up Evaluation of Houston ParentChild Development Center: School Performance," Journal of Early Intervention, $15(3), 226-236$.

Johnson, J. S., And E. L. Newport (1989): "Criticle Period Effects in Second Language Learning: The Influence of Maturational State on the Acquisition of English as a Second Language," Cognitive Psychology, 21, 60-99.

Jöreskog, K. G., And A. S. Goldberger (1975): "Estimation of a Model with Multiple Indicators and Multiple Causes of a Single Latent Variable," Journal of the American Statistical Association, 70(351), 631-639.

Judge, T. A., A. Erez, J. E. Bono, and C. J. Thorensen (2002): "Are Measures of Self-Esteem, Neuroticism, Locus of Control, and Generalized Self-Efficacy Indicators of a Common Core Construct?," Journal of Personality and Social Psychology, 83(3), 693-710.

Kahneman, D., and A. B. Krueger (2006): "Developments in the Measurement of Subjective Well-Being," Journal of Economic Perspectives, 20(1), 3-24.

Kahneman, D., A. B. Krueger, D. A. Schrade, N. Schwarz, and A. A. Stone (2004): "A Survey Method for Characterizing Daily Life Experience: The Day Reconstruction Method (DRM)," Science, 306(5702), 1776-1780.

Kendall, P., And L. Wilcox (1979): "Self-Control in Children: Development of a Rating Scale," Journal of Consulting and Clinical Psychology, 47, 1020-1029.

Kirby, K. N. (1997): "Bidding on the Future: Evidence Against Normative Discounting of Delayed Rewards," Journal of Experimental Psychology. General, 126(1), 54-70.

Knudsen, E. (2004): "Sensitive Periods in the Development of the Brain and Behavior," Journal of Cognitive Neuroscience, 16(4), 1412-1425. 
Knudsen, E., J. Heckman, J. Cameron, and J. Shonkoff (2006): "Economic, Neurobiological and Behavioral Perspectives on Building America's Future Workforce," World Economics, 7(3), 14-41.

Krueger, A. B., and D. SchKade (2008): "Sorting in the Labor Market: Do Gregarious Workers Flock to Interactive Jobs?," Journal of Human Resources, 43(4), 859-883.

Leibowitz, A. (1974): "Home Investments in Children," Journal of Political Economy, 82(2, Part 2), 111-131.

Madden, G. J., A. M. Begotka, B. R. Raiff, and L. L. Kastern (2003): "Delay Discounting of Real and Hypothetical Rewards," Experimental and Clinical Psychopharmacology, 11(2), 139-145.

Masten, A. S., K. B. Burt, and J. D. Coatsworth (2006): "Competence and Psychopathology in Development," in Developmental Psychopathology: Risk, Disorder, ed. by D. Cicchetti, and D. J. Cohen, vol. 2, pp. 696-738. John Wiley and Sons, Hoboken.

McClelland, D. C., R. Koestner, and J. Weinberger (1989): "How do SelfAttributed and Implicit Motives Differ?," Psychological Review, 96(4), 690-702.

Moretti, E. (2004): "Estimating the Social Return to Higher Education: Evidence from Longitudinal and Repeated Cross-sectional Data," Journal of Econometrics, 121(1), 175-212.

Morgeson, F., M. Campion, R. Dipboye, J. Hollenbeck, K. Murphy, and N. Schmitt (2007): "Reconsidering the use of Personality Tests in Personnel Selection Contexts," Personal Psychology, 60, 683-729.

Mueller, G., And E. Plug (2006): "Estimating the Effect of Personality on Male and Female Earnings," Industrial and Labor Relations Review, 60(1), 3-22. 
Murnane, R. J., J. B. Willett, M. J. Braatz, and Y. Duhaldeborde (2000): “Do Different Dimensions of Male High School Students' Skills Predict Labor Market Success a Decade Later? Evidence from the NLSY," Economics of Education Review, 20(4), 311-320.

NewPort, E. (1990): "Maturational Constraints on Language Learning," Cognitive Science, 14(1), 11-28.

O’Connor, T. G., M. Rutter, C. Beckett, L. Keaveney, J. M. Kreppner, and the English and Romanian Adoptees Study Team (2000): "The Effects of Global Severe Privation on Cognitive Competence: Extension and Longitudinal Follow-Up," Child Development, 71(2), 376-390.

Osborne-Groves, M. (2005): "How Important is your Personality? Labor Market Returns to Personality for Women in the US and UK," Journal of Economic Psychology, $26,827-841$.

Peterson, J., and N. Zill (1986): "Marital Disruption, Parent-Child Relationships, and Behavior Problems in Children," Journal of Mariage and Family, 48(2), 295-307.

Roberts, B., P. Harms, J. Smith, D. Wood, and M. Webb (2006): "Using Multiple Methods in Personality Psychology," in Handbook of Multimethod Measurement in Psychology, ed. by M. Eid, and E. Diener, chap. 22, pp. 321-335. American Psychological Association, Washington, DC.

Roberts, B., N. Kuncel, R. Shiner, A. Caspi, and L. Goldberg (2007): "The Power of Personality," Perspectives on Psychological Science, 2(4), 313-345.

Roberts, B., K. Walton, and W. Viechtbauer (2006): "Patterns of Mean-Level Change in Personality Traits Across the Life Course: A Meta-Analysis of Longitudinal Studies," Psychological Bulletin, 132, 1-25.

Rosenberg, M. (1965): Society and the Adolescent Self-Image. Princeton University Press, Princeton, New Jersey. 
Rothbart, M. K. (1981): "Measurement of Temperament in Infancy," Child Development, 52, 569-578.

Rothbart, M. K., S. A. Ahadi, and D. E. Adams (2000): "Temperament and Personality: Origins and Outcomes," Journal of Personality and Social Psychology, 78(1), 122-135.

Rothbart, M. K., and M. Bates (2006): "Temperament," in Handbook of Child Psychology Vol. 3 - Social, Emotional and Personality Development, ed. by W. Damon, N. Eisenberg, and R. M. Lerner, pp. 99-166. Wiley-Interscience, New York.

Rotter, J. (1966): Generalized Expectancies for Internal versus External Control of Reinforcement. American Psychological Association, Washington, DC.

Rutter, M. (1967): “A Children's Behavior Questionnaire for Completion by Teachers: Preliminary Findings," Journal of Child Psychology and Psychiatry, 8, 1-11.

(2006): Genes and Behavior: Nature-Nurture Interplay Explained. Blackwell Publishers, Oxford.

Schweinhart, L. J., H. V. Barnes, and D. P. Weikart (1993): Significant Benefits - The High/Scope Perry Preschool Study Through Age 27. High/Scope Educational Research Foundation, Ypsilanti, Michigan.

SEgal, C. (2008): "Classroom Behavior," Journal of Human Resources, 43(4), 783-813.

Shamosh, N., and J. Gray (2008): "Delay Discounting and Intelligence: A MetaAnalysis," Intelligence, 36(4), 289-305.

Shiner, R., And A. Caspi (2003): "Personality Differences in Childhood and Adolescence: Measurement, Development, and Consequences," Journal of Child Psychology and Psychiatry, 44(1), 2-32.

Shonkoff, J., And D. Phillips (2000): From Neurons to Neighborhoods: The Sience of Early Child Development. National Academy Press, Washington D.C. 
Spence, A. (1973): "Job Market Signaling," Quarterly Journal of Economics, 87(3), $355-374$.

Tangney, J., R. Baumeister, and M. Boone (2004): "High Self-Control Predicts Good Adjustment, Less Pathology, Better Grades, and Interpersonal Success," Journal of Personality, 72, 271-322.

Tellegen, A. (1985): "Structures of Mood and Personality and their Relevance to Assessing Anxiety, with an Emphasis on Self-Report," in Anxiety and the Anxiety Disorders, ed. by H. Tuma, and J. Maser, pp. 681-706. Lawrence Erlbaum Associates, Hillsdale, New Jersey.

Thomas, A., And S. Chess (1977): Temperament and Development. Brunner/Mazel, New York.

Thomas, A., S. Chess, And H. G. Birch (1968): Temperament and Behavior Disorders in Children. New York University Press, New York.

Turkheimer, E., A. Haley, M. Waldron, B. D'Onofrio, and I. Gottesman (2003): "Socioeconomic Status Modifies Heritability of IQ in Young Children," Psychological Science, 14(6), 623-628.

UrzuA, S. (2008): "Racial Labor Market Gaps: The Role of Abilities and Schooling Choices," Journal of Human Resources, 43(4), 919-971.

VAndenberghe, V. (2007): "Family Income and Tertiary Education Attendance across the EU: An empirical assessment using sibling data," CASE Paper 123, Centre for Analysis of Social Exclusion (CASE), London.

WebB, E. (1915): "Character and Intelligence," British Journal of Psychology, 1(3), $1-99$.

Wolfe, R., And S. Johnson (1995): "Personality as a Predictor of College Performance," Educational and Psychological Measurement, 55(2), 177-185. 
Wood, D. (2007): "Using PRISM to Compare the Explanatory Value of General and Role-Contextualized Trait Ratings," Journal of Personality, 76(6), 1103-1126.

Wössmann, L. (2008): "Efficiency and Equity of European Education and Training Policies," International Tax and Public Finance, 15, 199-230. 
Table 1: Personality Models and Sub-Factors

\begin{tabular}{|c|c|c|}
\hline Inventory & Factors & Facets \\
\hline \multirow[t]{5}{*}{ Big Five (Goldberg, 1971) ${ }^{a}$} & Openness to Experience & $\begin{array}{l}\text { Fantasy, Aesthetics, Feelings, } \\
\text { Actions, Ideas, Values }\end{array}$ \\
\hline & Conscientiousness & $\begin{array}{l}\text { Competence, Order, } \\
\text { Dutifulness, Achievement } \\
\text { Striving, Self-Control/ } \\
\text { Self-Discipline, Deliberation }\end{array}$ \\
\hline & Extraversion & $\begin{array}{l}\text { Warmth, Gregariousness, } \\
\text { Assertiveness, Activity, } \\
\text { Excitement Seeking, Positive } \\
\text { Emotions }\end{array}$ \\
\hline & Agreeableness & $\begin{array}{l}\text { Trust, Straightforwardness, } \\
\text { Altruism, Compliance, } \\
\text { Modesty, Tender-Mindedness }\end{array}$ \\
\hline & Neuroticism & $\begin{array}{l}\text { Anxiety, Vulnerability, } \\
\text { Depression, Self-Consciousness, } \\
\text { Impulsiveness, Hostility }\end{array}$ \\
\hline \multirow[t]{3}{*}{$\mathrm{MPQ}^{b}$ (Tellegen, 1985) } & Negative Emotionality & $\begin{array}{l}\text { Stress Reaction, Alienation, } \\
\text { Aggression }\end{array}$ \\
\hline & Constraint & $\begin{array}{l}\text { Control, Traditionalism, Harm } \\
\text { Avoidance }\end{array}$ \\
\hline & Positive Emotionality & $\begin{array}{l}\text { Achievement, Social Closeness, } \\
\text { Well-Being }\end{array}$ \\
\hline \multirow[t]{3}{*}{ Big Three (Eysenck, 1991) } & Neuroticism & $\begin{array}{l}\text { Anxious, Depressed, } \\
\text { Guilt-Feeling, Low Self-Esteem, } \\
\text { Tease, Irrational, Shy, Moody, } \\
\text { Emotional }\end{array}$ \\
\hline & Psychoticism & $\begin{array}{l}\text { Aggressive, Cold, Egocentric, } \\
\text { Impersonal, Anti-Social, } \\
\text { Unempathic, Tough-Minded, } \\
\text { Impulsive }\end{array}$ \\
\hline & Extraversion & $\begin{array}{l}\text { Venturesome, Active, Sociable, } \\
\text { Carefree, Lively, Assertive, } \\
\text { Dominant }\end{array}$ \\
\hline $\mathrm{JPI}^{c}$ (Jackson, 1976) & $\begin{array}{l}\text { Anxiety, Breadth of Interest, Complexity, Conformity, } \\
\text { Energy Level, Innovation, Interpersonal Warmth, } \\
\text { Organization, Responsibility, Risk Taking, Self-Esteem, } \\
\text { Social Adroitness, Social Participation, Tolerance, Value } \\
\text { Orthodoxy, Infrequency }\end{array}$ & \\
\hline Big Nine (Hough, 1992) & $\begin{array}{l}\text { Adjustment, Agreeableness, Rugged Individualism, } \\
\text { Dependability, Locus of Control, Achievement, Affiliation, } \\
\text { Potency, Intelligence }\end{array}$ & \\
\hline
\end{tabular}

italic: Affiliation of facet is still in debate (see Bouchard and Loehlin, 2001).

see also Costa and McCrae (2008)

Multidimensional Personality Questionnaire.

$c$ Jackson Personality Inventory.

Source: Bouchard and Loehlin (2001) and own inquiry. 


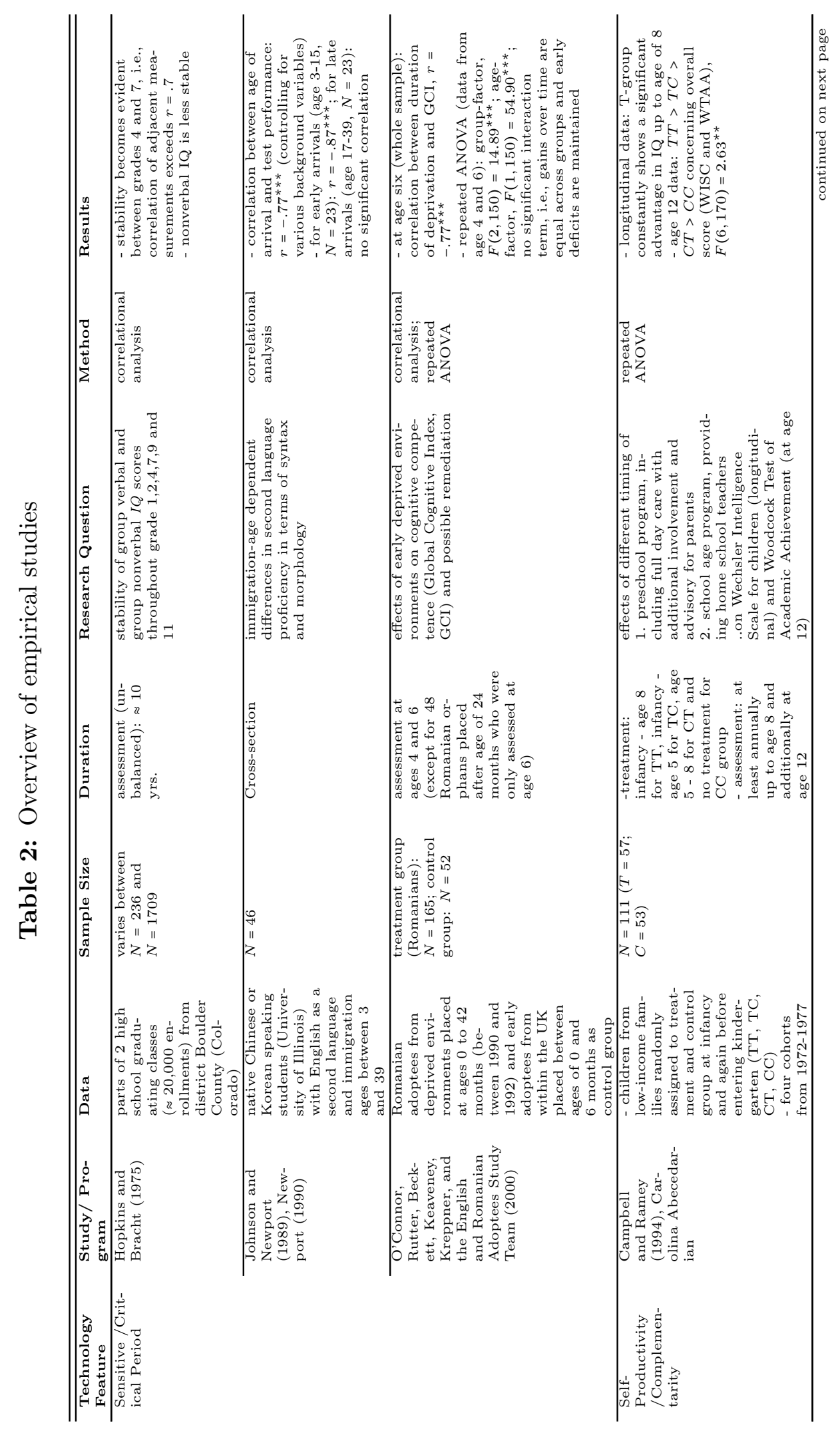




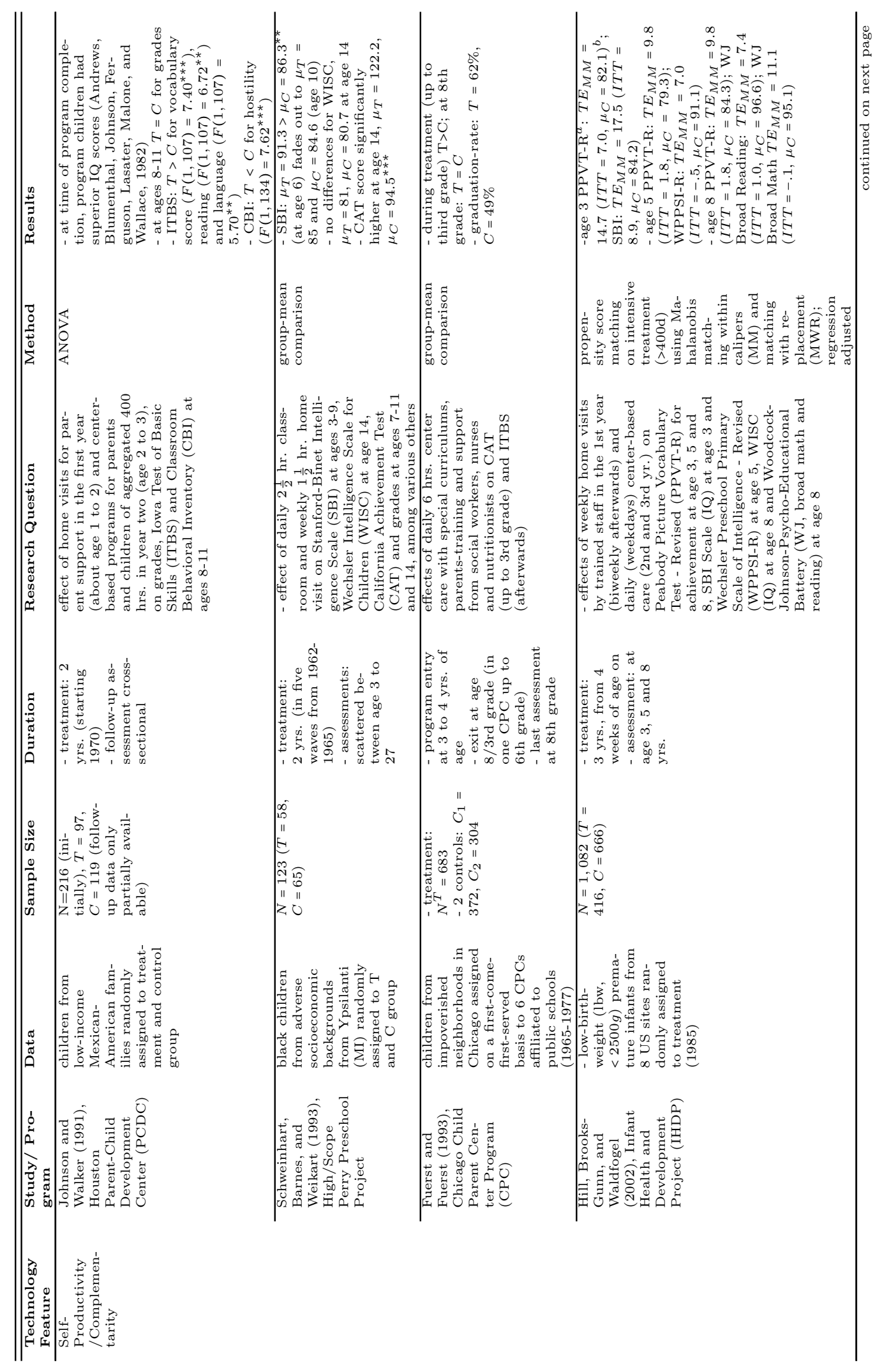




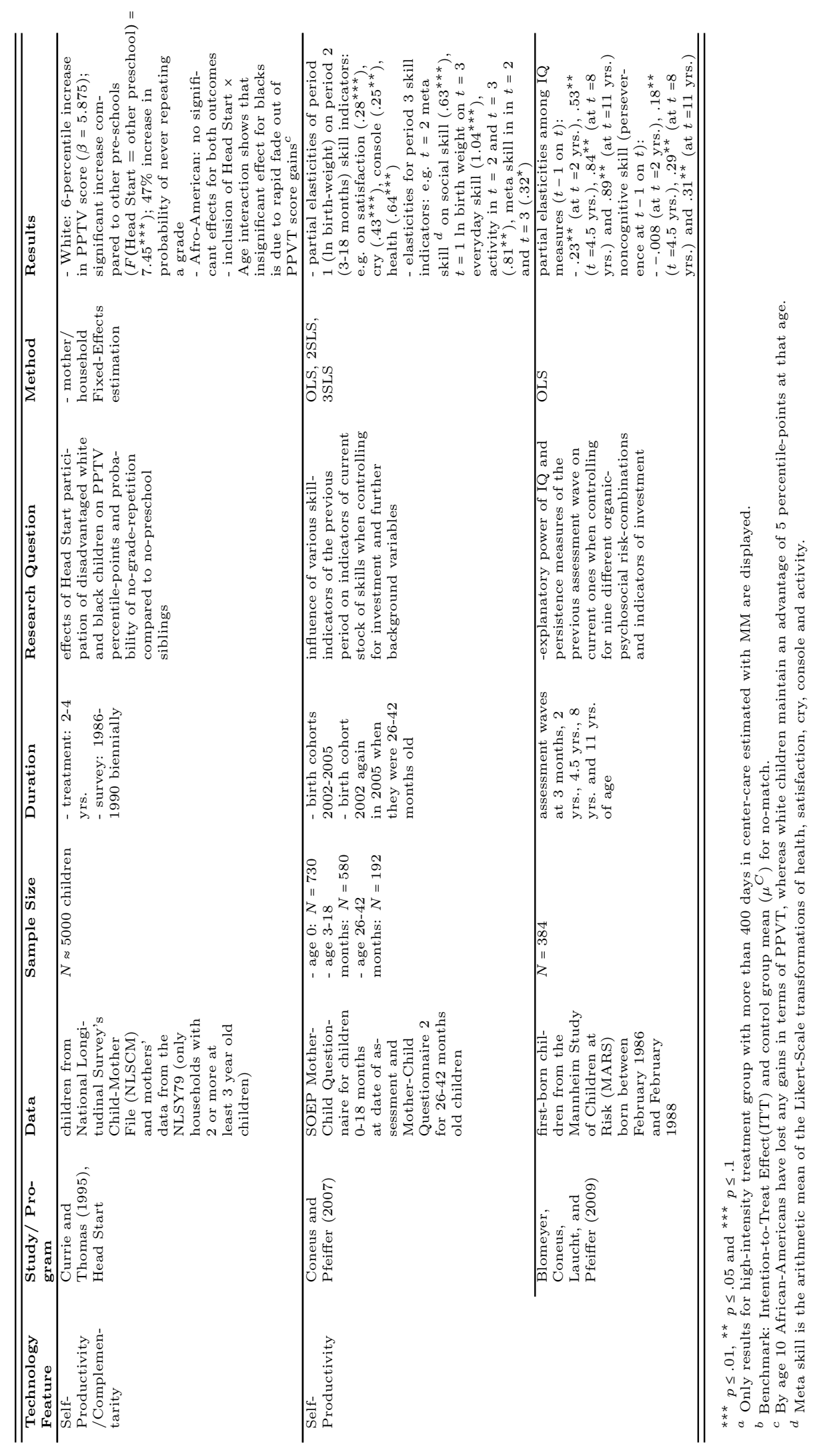




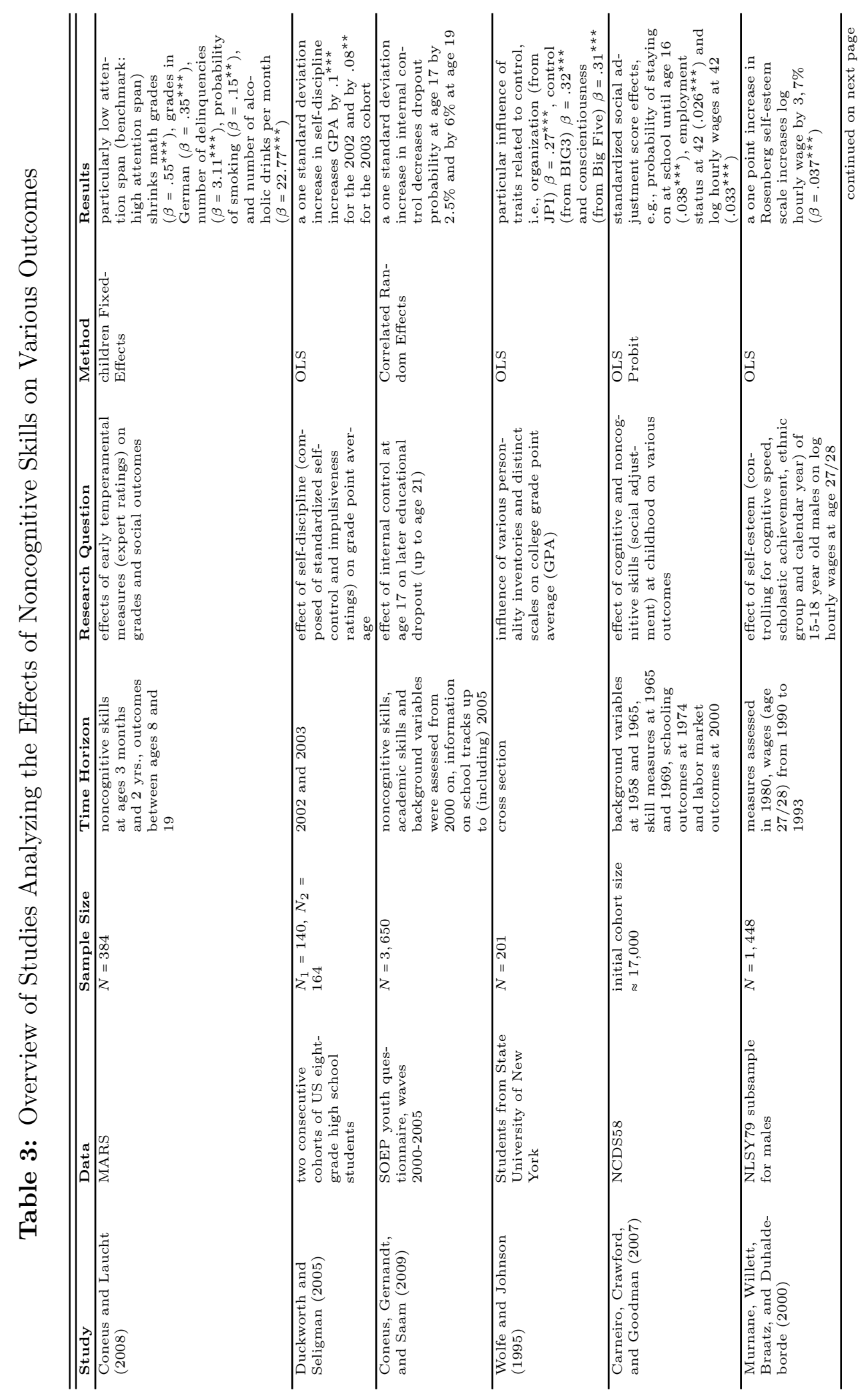




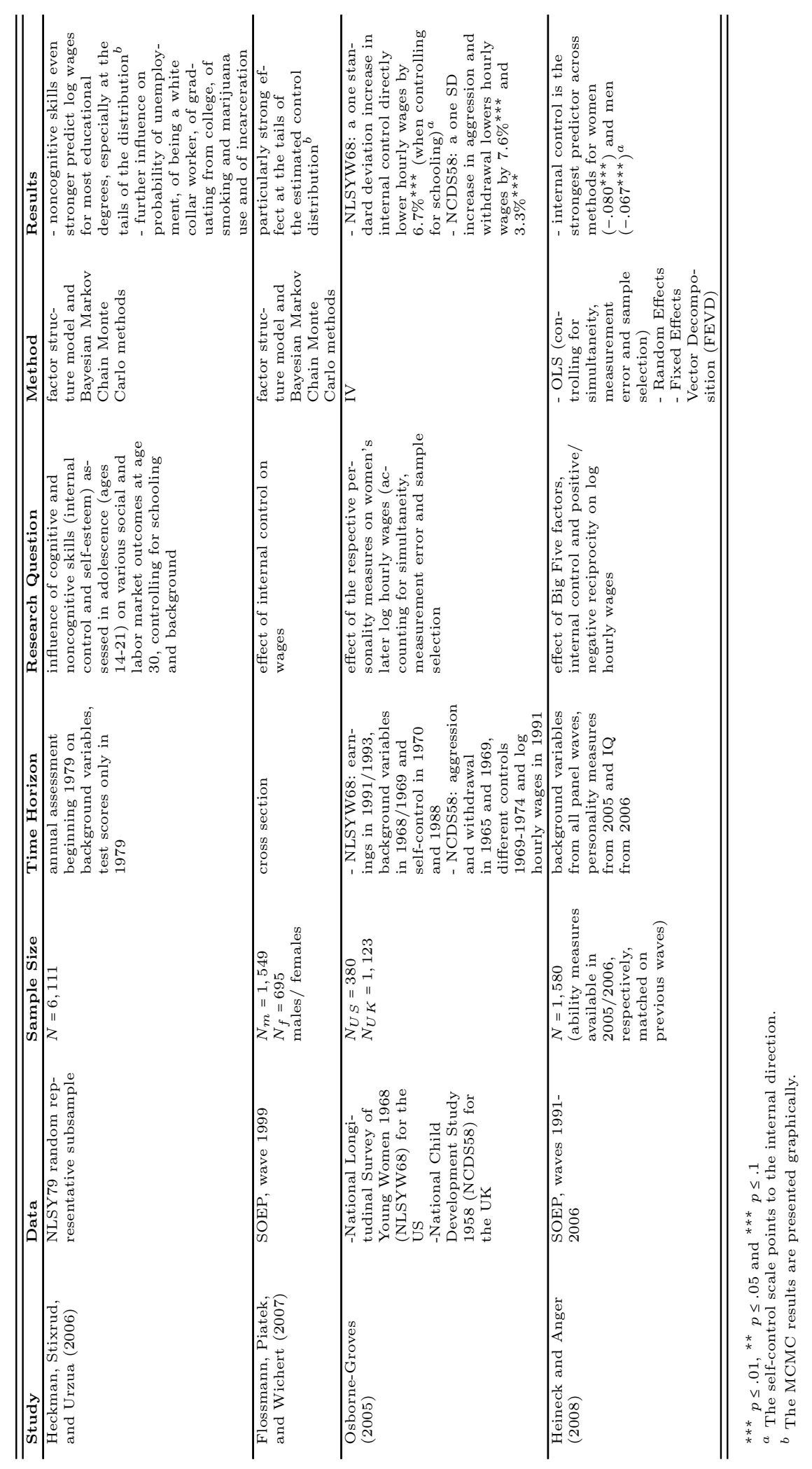




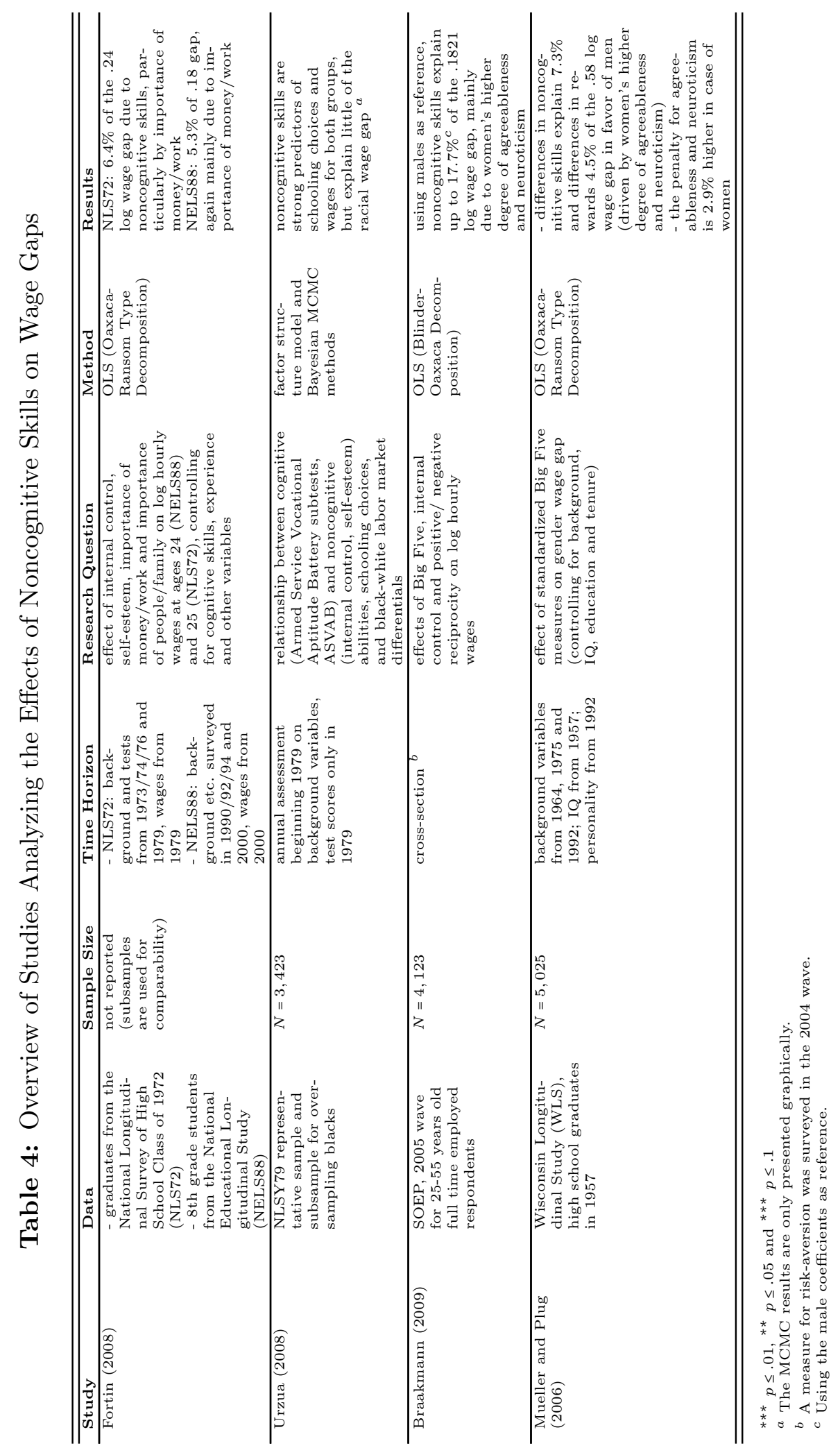




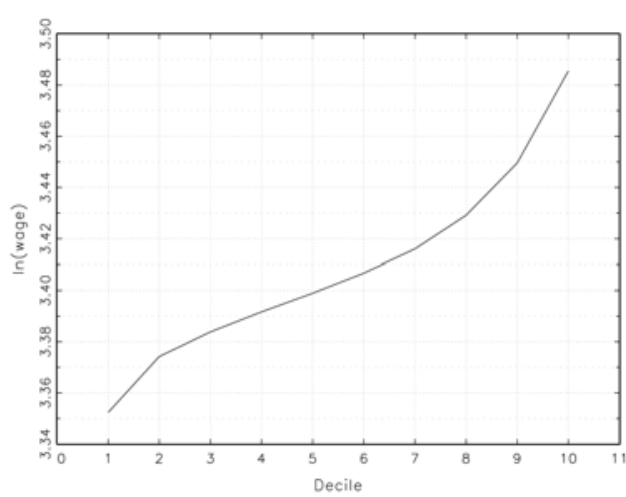

(a)

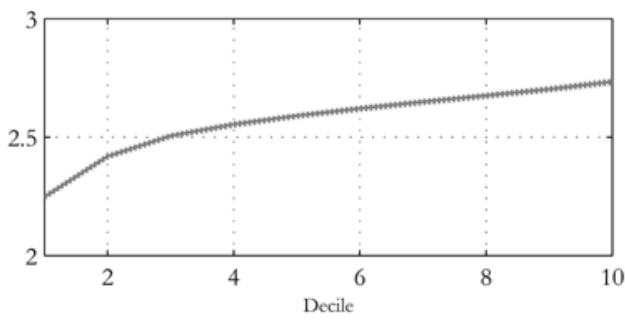

(c)

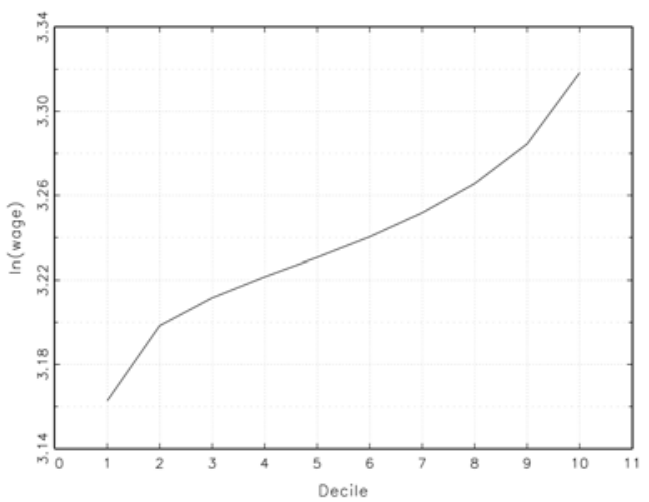

(b)

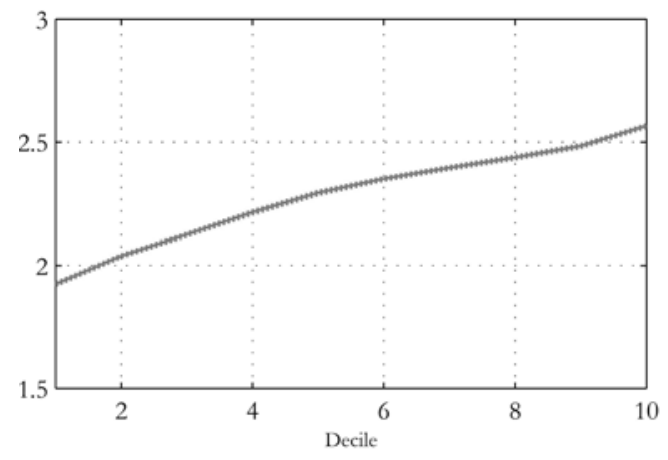

(d)

Figure 1: Net effect of noncognitive skills on log wages for 30-year old males and females in Germany and the United States. Upper panel: males (a) and females (b) in Germany. Lower panel: males (c) and females (d) in the United States. Sources: Flossmann, Piatek, and Wichert (2007) and Heckman, Stixrud, and Urzua (2006). 